\title{
Long-Term Flow-Through Column Experiments and Their Relevance to Natural Granitoid Weathering Rates
}

3

4

Art F. White ${ }^{1}$, Marjorie S. Schulz*, Corey R. Lawrence, Davison V. Vivit ${ }^{2}$

5

and David A. Stonestrom

6

U. S. Geological Survey, Menlo Park, CA 94025

7

${ }^{1}$ emertius, ${ }^{2}$ deceased

8

*Corresponding author. Tel. 1-6503294518

9

Emailmschulz@usgs.gov

10 

Abstract

Four pairs of fresh and partly-weathered granitoids, obtained from well-characterized watersheds-Merced River, CA, USA; Panola, GA, USA; Loch Vale, CO, USA, and Rio Icacos, Puerto Rico-were reacted in columns under ambient laboratory conditions for 13.8 yrs, the longest running experimental weathering study to date. Low total column mass losses ( $<1$ wt. $\%$ ), correlated with the absence of pitting or surface roughening of primary silicate grains. BET surface area $\left(\mathrm{S}_{\mathrm{BET}}\right)$ increased, primarily due to Fe-oxyhydroxide precipitation. Surface areas returned to within factors of 2 to 3 of their original values after dithionite extraction. Miscible displacement experiments indicated homogeneous plug flow with negligible immobile water, commonly cited for column experiments. Fresh granitoid effluent solute concentrations initially declined rapidly, followed by much slower decreases over the next decade. Weathered granitoid effluent concentrations increased modestly over the same time period, indicating losses of natural Fe-oxide and/or clay coatings and the increased exposure of primary mineral surfaces. Corresponding (fresh and weathered) elemental effluent concentrations trended toward convergence during the last decade of reaction. NETPATH/PHREEQC code simulations indicated non-stoichiometric dissolution involving $\mathrm{Ca}$ release from disseminated calcite and excess $\mathrm{K}$ release from interlayer biotite. Effluent ${ }^{87} \mathrm{Sr} /{ }^{85} \mathrm{Sr}$ ratios reflected a progressive weathering sequence beginning and ending with ${ }^{87} \mathrm{Sr} /{ }^{85} \mathrm{Sr}$ values of plagioclase with an additional calcite input and a radiogenic biotite excursion proportional to the granitoid ages. saturated with kaolinite and strongly under-saturated with plagioclase, consistent with kinetically-limited weathering in which solutes such as $\mathrm{Na}$ varied with column flow rates. Effluent $\mathrm{Na}$ concentrations showed no clear trend with time during the last decade of reaction (fresh granitoids) or increased slowly with time (weathered granitoids). Analysis of cumulative $\mathrm{Na}$ release indicated that plagioclase dissolution achieved steady state in 3 of the 4 fresh granitoids during the last decade of reaction. Surface-area normalized plagioclase dissolution rates exhibited a narrow range (0.95 to $1.2610^{-13}$ moles $\mathrm{m}^{-2} \mathrm{~s}^{-1}$ ), in spite of significant stoichiometric differences $\left(\mathrm{An}_{0.21}\right.$ to $\left.\mathrm{An}_{0.50}\right)$. Rates were an order of magnitude slower than previously reported in shorter duration experiments but generally 2 to 3 orders of magnitude faster than corresponding natural analogs. CrunchFlow simulations indicated that more than a 
hundredfold decrease in column flow rates would be required to produce near-saturation reaction affinities that would start to slow plagioclase weathering to real-world levels. Extending simulations to approximate long term weathering in naturally weathered profiles required additional decreases in the intrinsic plagioclase dissolution and kaolinite precipitation rates and relatively large decreases in the fluid flow rate, implying that exposure to reactive mineral surfaces is significantly limited in the natural environment compared to column experiments.

\section{INTRODUCTION}

Granitoid rocks are ubiquitous in the earth's crust, comprising about $60 \%$ of the continental land mass. Granitoid weathering is complex and inherently heterogeneous with different minerals weathering at different rates, causing their relative abundances in the solid and solute products to change with time. Granitoid weathering occurs along grain boundaries, resulting in physical degradation, sap rock, and grus formation (Piotr and Thomasb, 2002). Rates of physical disaggregation may be more than an order of magnitude faster than rates of chemical weathering (Dixon et al., 2001; Yokoyama and Matsukura, 2006). Large rate increases due to physical decomposition have also been observed experimentally under low $\mathrm{pH}$ conditions (Ryu et al. 2011).

Both the chemical and physical weathering of granitoids may be initially dominated by soluble and highly reactive accessory minerals such as calcite and epidote (Mast et al., 1990; 1999a; Price et al., 2002; White et al., 2005a) or by oxidation of minerals containing reduced Fe (Taylor et al., 2000; Buss et al., 2008). The relative weathering rates of granitoid minerals vary due to changing environmental conditions such as $\mathrm{pH}$ and temperature. Due to lower activation energies, for example, granitoid weathering under low temperature environments is dominated by biotite relative to feldspar (Anderson et al., 1997; White et al., 1999a). Finally, weathering contributions are related to differences in mineral solubilities. For example, plagioclase and Kfeldspar dissolution rates are comparable in experimental solutions far from thermodynamic saturation (Blum, 1994; Brantley, 2004). However, under natural near-saturated conditions, feldspar weathering in granites becomes highly selective due to the lower solubility of Kfeldspar relative to plagioclase (Fritz, 1988; Maher et al., 2009; White et al., 2001). 
Despite their importance, far fewer experimental studies have addressed the weathering complexities of granitoid rocks compared to their individual mineral components. Table 1 summarizes field and laboratory-based approaches. Long-term experiments, lasting up to a decade, measured mass losses from crushed or slabbed granitoids buried in soils or exposed to groundwater or rain. Shorter-term laboratory weathering of crushed granitoids in batch, flowthrough or column reactors measured release rates of major solutes, trace metals, REEs and isotopes. Many of these experiments were conducted at lower $\mathrm{pH}$ or lower rock/water ratios than occur during natural weathering.

The time span commonly associated with natural weathering is one parameter that cannot be experimentally reproduced (White and Brantley, 2003). While certainly not overcoming this obstacle, the present study, involving pairs of crushed fresh and weathered granitoids, extends the time span beyond any yet achieved for laboratory weathering. Previous papers described initial phases of this experiment and focused on imposed temperature variations, effects of trace amounts of disseminated calcite, and the distribution of $\mathrm{Sr}$ isotopes on column effluents (Bullen et al., 1999; White et al., 1999a; White et al., 1999b). The present paper presents final results, focusing on the last decade of the experiment. watersheds: the Merced River in Yosemite National Park, California, USA; the Loch Vale watershed in Rocky Mountain National Park, Colorado, USA; the Panola Mountain Research Watershed near Atlanta, Georgia, USA; and the Rio Icacos watershed in the Luquillo Mountains of Puerto Rico (Table 2). References describing these watersheds are contained in White et al. (1999a; 1999b). Fresh samples were collected from outcrops (or drill core, for Panola) and weathered samples from surface exposures exhibiting various degrees of Fe-staining and physical disaggregation. As in previous reports, we refer to granitoid rocks by their watershed association rather than their geologic names (Table 2). Although all the granitoids were subjected to experimental weathering, we refer to the granitoid pairs as fresh (crushed whole rock granitoids) and weathered (crushed granitoids exposed to some degree of prior natural weathering). 
Appendix I contains rock compositions and elemental losses and gains of weathered relative to fresh granitoids as reported as tau values, where a tau value of -1 represents complete loss of an element, and 0 no change (Brimhall and Dietrich, 1987). Elemental losses associated with weatherable primary silicates vary from $\sim 0$ to $>0.75$. Mineral abundances and compositions for the fresh granitoids are reported in Appendix II. White et al. (1999a) described the experimental column setup in detail. Briefly, granitoids were crushed and the 0.25 to $0.85-\mathrm{mm}$ fraction retained after removal of adhering fines. Samples (750 g total) were loaded into $2.4 \mathrm{~cm}$ ID x $100 \mathrm{~cm}$ glass columns. (For details on experimental setup see also Figs. S1 and S2.) DI water was introduced through fritted supports at column bases from an elevated polyethylene reservoir through which a $5 \% \mathrm{CO}_{2}-95 \%$ air mixture was continually bubbled. To minimize gas trapping, fluid flow was directed upward from the column base and effluents collected at the column top (this geometry is the reverse to that of natural soil weathering). Effluents passed through $0.45 \mu \mathrm{m}$ acetate filters and then through $0.5 \mathrm{~mm}$ capillary tubes whose internal diameters were further restricted by drawing out over a Bunsen burner. Flow rates were calibrated to $10 \pm$ $0.5 \mathrm{ml} / \mathrm{hr}$. Although, not sterilized, no obvious biological activity was observed in the columns during the experiments. When the columns were dismantled, SEM analyses of sediment nearest the inlet indicated sparse biological activity (biofilms) mostly at biotite edge sites (Fig. S3).

Ambient temperatures $\left(22 \pm 2{ }^{\circ} \mathrm{C}\right)$ were maintained except for periods of imposed temperature excursions of 5 to $37{ }^{\circ} \mathrm{C}$ (White et al., 1999b). Collection bottles were replaced on a weekly basis, weighed and filtered for chemical analyses. Solute cations and Si were determined by inductively coupled plasma-mass spectroscopy (ICP-MS) and alkalinity by an auto-titrator. Limited anion analyses were performed by ion chromatography. ${ }^{87} \mathrm{Sr} /{ }^{86} \mathrm{Sr}$ ratios were determined by thermal ionization using a Finnegan-MAT 261 mass spectrometer (Bullen et al., 1999). In situ pore-water $\mathrm{pH}$ values were estimated at the end of the experiments by rapid successive collection of volume increments from the columns. Exchangeable base cations and ${ }^{87} \mathrm{Sr} /{ }^{86} \mathrm{Sr}$ were determined by passing $0.1 \mathrm{M} \mathrm{NH}_{4}$-acetate solutions through the columns. Total exchange capacity (CEC) measured by subsequent Mg exchange.

Post-experiment miscible displacement experiments characterized the flow regime including saturated hydraulic conductivities and hydrodynamic dispersion coefficients following methods in Klute and Dirksen (1986) and van Grinsven and Reimsdijk (1992). Briefly, water 
132 was pushed through each column at a nominal flow rate of $10 \mathrm{~mL} \mathrm{~h}{ }^{-1}$ using paired chromatographic pumps. A variable-reluctance pressure transducer connected to a data logger recorded the pressure drop associated with flow. The outlet solution passed through a conductivity cell to determine electrolytic activity of the effluent. After steady conditions were established with DI water, the inlet solution was switched to 0.05 molar $\mathrm{MgCl}_{2}$. Breakthrough curves were analyzed using standard regression techniques incorporated into CFITIM (van Grinsven and Reimsdijk, 1992).

Statistical characterizations were performed using the ORIGIN PRO 8 graphing program. Mineral saturations and contributions to solute effluents were determined using PHREEQC/NETPATH model (Plummer et al., 1994; Parkhurst and Appelo, 1999). Comparisons of parameters impacting experimental and natural weathering were made for the Merced granitoids using the CrunchFlow reactive transport model (Steefel and Yabusaki, 1996). The initial CrunchFlow model parameterizations were based on prior CrunchFlow simulations of the Santa Cruz, CA chrosequence soils by Maher et al. (2009) and Lawrence et al. (2014) and on FLOWTRAN simulations by Moore et al. (2012). The Santa Cruz and Merced weathering regimes are similar, except that the Merced soils contain a slightly different starting mineral composition, have lower recharge rates, and have weathered for a longer period of time.

Two sets of CrunchFlow simulations were performed: (1) short-term column-scale simulations and (2) long-term field-scale simulations. Short-term simulations of Merced granitoid weathering in the experimental columns were discretized with 10 nodes, evenly distributed over a $100 \mathrm{~cm}$ column length scale. For both sets of CrunchFlow simulations, fixed model parameters included boundary conditions, primary species composition, protolith mineral volumes, and volume-dependent BET surface areas (Table 6). Only dissolution of primary plagioclase and $\mathrm{K}$-feldspar and precipitation of kaolinite were considered. The parameter values differed somewhat between short- and long-term simulations on account of differences in starting materials and weathering conditions. The short-term model simulations were run for the equivalent of 15 yrs with daily time-steps and a suite of model simulations were run spanning hypothetical Darcy flow rates ranging from to 0.003 to $160 \mathrm{~m} \mathrm{yr}^{-1}$, the upper bound representing flow rate of the column experiments. Fixed model parameters for the short-term simulations were from laboratory measurements of column material and the effluent produced during the 
weathering study (as reported below). The mineral dissolution rates used in the short-term simulations (baseline values in Table 7) came from previous CrunchFlow simulations of water rock interactions at the Santa Cruz Marine Terraces (Maher et al., 2009; Lawrence et al., 2014). Long-term simulations were discretized with 20 nodes evenly spaced over a $5 \mathrm{~m}$ soil column. Simulations were run for the equivalent of $3000 \mathrm{kyr}$ with yearly time-steps, however, for conciseness only results from Riverbank soil (250 kyr) are reported here. The parameters for the long-term simulations were taken from measurements made by White et al., 1996; 2005 and compiled by Moore et al., 2012, who used a comparable reactive transport model, FLOWTRAN, to simulate field weathering of the Merced parent material. For the long-term simulations, we varied weathering rate constants (plagioclase) and fluid-flow until modeled data best matched observations (Table 7). We compared two different mineral weathering rate law formulations: (1) transition state theory (TST) describing a linear rate decrease describing a single elementary reaction or (2), a nonlinear parallel rate law (PRL) describing separate reactions dominating fast far-from equilibrium (FFE) and slow close-to-equibrium (CTE) reactions. Maher et al (2009) and Lawrence et al. (2014) provide a more detailed description of these CrunchFlow subroutines.

\section{RESULTS}

The number of columns studied, the long duration of the experiments and the number of parameters characterized produced a very large data set which cannot be succinctly characterized in a single paper; however, all effluent data are provided in the supplemental tables. Here we characterize the results using the Merced granitoid columns as examples. Other granitoid data are discussed where significantly different or where enhancement of a point or conclusion is required. The summary of properties of the fresh Merced granitoid column are listed in Table 3 along with that of the Riverbank soil, which comprise end-members of the extensively studied Merced chronosequence (see references in Table 3). The following sections of the paper describe the main parameters of interest.

\subsection{Mineralogical Changes}

Less than one percent of granitoid masses were lost during the 14 years of reaction, based on total effluent fluxes and solid state compositions. Likewise, post-run SEM observations failed 
to detect any significant increases in surface pitting or roughening of the fresh mineral surfaces that are commonly associated with natural weathering (e.g., the Merced soil, Table 3; White et al., 1996). Varied amounts of red Fe-oxyhydroxide stains formed on mineral grains near the inlet ports, most prominantly in the Fe-rich Merced and Rio Icacos columns (Fig.1b, Fig. S4 and S5). In addition, cemented clusters of grains occurred throughout all columns (Figs. 1a, and Figs. S4 and S5) suggesting localized Fe release from Fe-silicates or most likely trace amounts of pyrite common in granitoids (e.g., the Rio Icacos Granite; Seiders, 1971). Effluent sulfate concentrations decreased to below detection levels during the first year of the experiment implying that pyrite dissolution reaction was fast and did not significantly impact long-term column reactions (White et al. 1999). Fe-oxyhydroxide formation was previously reported in column studies of other granitoids (Afifi et al., 1985).

While no additional secondary phases were positively identified within the columns, white precipitates formed on the surfaces of the solute collection bottles. Nitric acid dissolution recovered mostly $\mathrm{Al}$ with subordinate amounts of $\mathrm{Si}$, implying the formation of an Al-hydroxide, i.e., possibly amorphous, or a short range order gibbsite and/or a kaolinite phase. $\mathrm{CO}_{2}$ degassing in sample bottles produced higher $\mathrm{pH}$ conditions than in the columns; making the case that insitu formation of secondary phases in the columns is geochemically unfavored. Similar white precipitates collected in previous silicate column studies were described as poorly crystallineamorphous Al-hydroxides (Afifi et al., 1985).

\subsection{Mineral Surface Areas}

Initial BET surface areas $\left(\mathrm{S}_{\mathrm{BET}}\right)$ of the fresh granitoids ranged between 0.077 and 0.103 $\mathrm{m}^{2} \mathrm{~g}^{-1}$ (Table 4 and Fig. 1c). These values are similar to the crushed El Capitan granite from the Merced drainage (Hausrath et al., 2009) and to averages of plagioclase and K-feldspar separates from granitoid soils in the Loch Vale watershed (Clow and Drever, 1996). The naturallyweathered granitoids exhibit both higher values and a larger range in $S_{\mathrm{BET}}$ than for the fresh granitoids (Table 4). Weathered Panola and Rio Icacos $S_{\mathrm{BET}}$ are significantly higher than for the Loch Vale and Merced granitoids, reflecting more intensive weathering of these older landforms.

$\mathrm{S}_{\mathrm{BET}}$ profiles at the end of reaction were always higher than their starting values (Fig. 1c and d). Elevated values occurred adjacent to fluid inlets $(<10 \mathrm{~cm}$ in Fig. 1c) corresponding to 
secondary Fe-oxyhydroxide formation. The Rio Icacos granitoid had the highest hornblende concentration $(0.46 \mathrm{wt} \%)$ and highest inlet surface area $\left(1.22 \mathrm{~m}^{2} \mathrm{~g}^{-1}\right)$. The Loch Vale Granite had the lowest values $\left(0.21 \mathrm{~m}^{2} \mathrm{~g}^{-1}\right.$ and $>0.1 \%$, respectively). A subset of reacted fresh granitoids, subjected to Fe extraction by dithionite (DCB), produced $\mathrm{S}_{\mathrm{BET}}$ column trends mimicking the untreated samples but at significantly lower values (Fig. 1d). Small differences in the initial and treated values (factors of 2 to 5) may be related to slight surface roughening, incomplete Fehydroxide removal, or opening of biotite interlayers as a result of DCB extraction (Lowell, 1967).

\subsection{Fluid Flow}

Average flow rates for the fresh and weathered Merced granitoids were only slightly slower than the initial calibrated rates of 8.5 to $9.0 \mathrm{ml} \mathrm{hr}^{-1}$ shown by the horizontal lines in Fig. 2a. However, both significantly faster $\left(\max \approx 16 \mathrm{ml} \mathrm{hr}^{-1}\right)$ and slower short-term rates $(\mathrm{min} \approx 4 \mathrm{ml}$ $\mathrm{hr}^{-1}$ ) occasionally occurred due to breakage and/or clogging of the capillary tips. Although not initially planned, such variations provided useful in documenting the effect of flow on weathering rates. A less desirable effect would be if flow rates exhibited consistent increases or decreases over the entire course of the experiments, potentially impacting long-term steady state conditions. Cumulative volumes of flow through the fresh granitoids were similar, and linear with time $\left(\mathrm{r}^{2}>0.99\right)$ implying that short-term changes in flow rates were random and produced no long-term extraneous signal (Fig. 2b).

In addition to the macroscopic flow rate, pore-level flow geometry is also important in controlling residence times of fluids in contact with mineral surfaces. If the flow field is highly heterogeneous, as represented by dual-porosity (mobile-immobile) pore-water models, the corresponding weathering rates will also be variable. A review of a large number of solute transport experiments by Haggerty et. al. (2004) indicated that immobile water usually played a key role in transport, even in sands. However, apparatus artifacts are often to blame (James and Rubin, 1972). In the present study, miscible displacement experiments uniformly indicated very narrow distributions of residence times within the columns (e.g., Fig. 2c). The movement of water through the pore space was well approximated by piston flow, with minimal, nearly symmetric tailing. Peclet numbers, representing the ratio of advective to diffusive transport $(\mathrm{P}=$ Lu/D), were much greater than one $(143<\mathrm{P}<4500)$, providing strong evidence of negligible 
impacts of solute exclusion, local non-equilibrium, and immobile water. $\mathrm{L}, \mathrm{u}$, and $\mathrm{D}$, are porescale characteristic length, local flow velocity, and solute diffusion coefficient, respectively. Dimensionless P values were calculated by CFITM directly from dimensionless breakthrough curves. Retardation factors, $\mathrm{R}$, reflecting adsorption of $\mathrm{Mg}^{+}$on exchange sites, were also relatively small, ranging from 1.0 to 1.6 , where $\mathrm{R}$ equals the number of pore-volumes eluted at $50 \%$ breakthrough. Note that $\mathrm{P}$ values do not indicate the degree to which reactive conditions are transport-limited. Indeed, due to interphase mass transport inherent in profile development, weathering rates in natural settings depend primarily on fluid residence times (i.e., flow velocity; Maher, 2010).

\subsubsection{Column Solutes}

Column effluent compositions during initial phases of the column experiments were previously described (White et al., 1999a; 1999b and White and Brantley, 2003). Data collected at longer times (4.0 to 13.8 yrs) are the focus of the present paper and are summarized in Table 5 (see supplemental tables for the complete data sets). Silica and alkalinity $\left(\mathrm{HCO}_{3}\right)$ dominated all column effluents, with concentrations (hence release rates) for fresh and weathered granitoids largely converging by the end of reaction. Initial solute concentrations were significantly lower in effluents from the weathered versus fresh granitoids, presumably reflecting their less-reactive surfaces. Perturbations during 1.5 and 2.5 yrs (Fig. 3) reflected experimentally-induced temperature changes $\left(6\right.$ to $\left.34^{\circ} \mathrm{C}\right)$ described by White et al. (1999b). Insets in Figure 3 show dilute effluents sampled during the last decade of reaction (Table 5 and supplemental tables). Data scatter reflects changes in experimental conditions, principally flow rate and analytical protocols related to instrument upgrades over time.

Solute concentrations in effluent from the fresh Merced granitoid generally exhibited small but statistically significant decreases over the last decade of the experiments (linear regression fits, Fig. 3). Potassium, $\mathrm{Mg}, \mathrm{Ca}, \mathrm{Si}$, and alkalinity concentrations declined by a factor of about 2. The decline in $\mathrm{Na}$, assumed to be solely dependent on plagioclase dissolution, is small compared to scatter, and statistically insignificant over long times. The other fresh granitoid columns showed similar trends with no or small statistical declines in Na. In contrast, weathered granitoid solutes, including $\mathrm{Na}$, generally exhibited small increases with time (Fig. 3; also see White and Brantley, 2003). 


\subsubsection{Column pH}

Column input $\mathrm{pH}$ (average $=4.65)$ corresponded to DI water saturated with $5 \% \mathrm{CO}_{2}($ Fig. 4a) and is comparable to many shallow soils with elevated $\mathrm{CO}_{2}$ from plant respiration (e.g., White et al., 2005b). In contrast, column discharge $\mathrm{pH}$ (average $=5.41$ ), measured from sample collection bottles, is representative of dilute solutions equilibrated with atmospheric $\mathrm{CO}_{2}($ Likens and Bormann, 1974). The estimated column in-situ $\mathrm{pH}$ values, measured by rapid plug-flow displacement from columns immediately at the end of the experiments, bracketed the input and sample bottle $\mathrm{pH}$ values (4.96 to 5.15). The slightly higher average $\mathrm{pH}$ values in the fresh granitoids, compared to their weathered counterparts, correlated with more concentrated effluents and faster reaction rates. The fresh Rio Icacos granite exhibited the highest $\mathrm{pH}$, consistent with more reactive calcic labradorite. Except for this granitoid, there is essentially no $\mathrm{pH}$ increase along the flow path of any the columns as would be expected if progressive silicate hydrolysis was occurring.

\subsubsection{Exchangeable Cations}

Cation exchange capacities (CEC) for the fresh and weathered granitoids, measured after reaction, were small compared to natural granitic soils $\left(0.14\right.$ to $0.33 \mathrm{meq} \mathrm{kg}^{-1}$ for the columns, versus $>10 \mathrm{meq} \mathrm{kg}^{-1}$ for their natural counterparts; White et al., 2005b, (supplemental table L). CECs determined on field samples from the naturally weathered Panola and Merced profile varied between 10 and $180 \mathrm{meq} \mathrm{kg}^{-1} \mathrm{~s}$, corresponding to significant clay and Fe-oxyhydroxide precipitation (White et al, 2001; 2005c). In the fresh granitoid columns total exchangeable $\mathrm{Ca}$ is the dominant column cation (Fig. 4b-e). Exchangeable $\mathrm{Ca}$ is less than $0.1 \%$ of the cumulative solute $\mathrm{Ca}$ released from the course of fresh Merced experiment. Exchangeable $\mathrm{Ca}$ is significantly greater for fresh Puerto Rico granitoid due to the high labradorite content, but is still equivalent to only $6 \%$ of the total solute $\mathrm{Ca}$ released. These low exchange capacities imply that the major solute cations are not well buffered with respect to changing external effects such as pore water flow (Fig. 2a). This condition is opposite of that for many natural soils in which high CECs serve as effective buffers to changes in solute compositions.

Hydrogen ions generally dominated over other base cations on the exchange sites (Fig 4b-e), which buffered solute column $\mathrm{pH}$ values. Increasing $\mathrm{pH}$ indicative of silicate hydrolysis was observed only in the Rio Icacos columns, where exchange sites were dominated by Ca rather 
than $\mathrm{H}^{+}$(Fig 4e). Base saturation, defined as the percentage of CEC occupied by cations other than $\mathrm{H}+$ and total $\mathrm{Al}$ (Driscoll et al., 1985), was low (2 to 23\%). Base saturation in the columns of this study is comparable to soils impacted by acid precipitation, a condition commonly occurring in watersheds underlain by granitoid rocks. The acidity of column input solution $(\mathrm{pH}=$ 4.6 at $5 \% \mathrm{CO}_{2}$ ) is slightly higher than acid precipitation, which has an average $\mathrm{pH}$ value of 4.0. The high exchangeable $\mathrm{H}^{+} / \mathrm{Al}$ ratio is also atypical of natural acid-impacted environments. Low base saturation reflects the rapid column flow rates and attendant low base cation weathering status rather than a strong acid input.

\subsection{Effluent thermodynamic saturation}

Mineral saturation indices (SI) are defined as the log ratio of aqueous activities, IAP, divided by the mineral solubility constants, $\mathrm{K}_{\mathrm{s}}\left(\mathrm{SI}=\log \mathrm{IAP} / \mathrm{K}_{\mathrm{s}}\right)$. Calculations were performed using the PHREEQC code (version 2), using $\mathrm{K}_{\mathrm{s}}$ values cited in the user's manual (Parkhurst and Appelo, 1999). Values of SI $<0$ thermodynamic under-saturation and values $>0$ denote supersaturation. The fresh granitoid effluents are initially saturated or supersaturated with respect to goethite (Fig. 5a). Rio Icacos effluents remain relatively high in Fe concentration. Solute Fe generally falls below detection limits for the other granitoids (Table 5). However, based on randomly distributed Fe-oxyhydroxide cemented clusters which occurred in all fresh granitoid columns (SEM/EDAX data Fig.1a and b; Figs. S4 and S5), secondary goethite was supersaturated locally, where pyrite dissolution occurred.

Both gibbsite and kaolinite are supersaturated in the initial effluents, principally due to high solute Al concentrations (Figs. 5b and 5c). Over longer time frames, effluents become closely equilibrated with gibbsite and slightly under saturated with kaolinite. As previously mentioned, neither phase was positively identified in reacted column material by SEM/EDAX, presumably due to poor crystallinity. The white precipitate formed in the collection bottles and composed of mainly $\mathrm{Al}$ with lesser $\mathrm{Si}$ indicate a possible mixed gibbsite-kaolinite phase, formed at a higher $\mathrm{pH}$ than existed in the columns (Fig. 4a).

Except for some early samples, effluents were significantly undersaturated with respect to primary aluminosilicates - as indicated by sequentially more negative SI values for biotite, Kfeldspar, and plagioclase (Fig 5d -f). Plagioclase solubility was calculated as albite. The 
saturation state for ferrous-Fe containing biotite is dependent on undefined column redox conditons, thus end-member phlogopite mica (no Fe) was used to estimate biotite solubility.

\subsection{Relationship Between Flow Rate and Solute Concentrations}

Mineral weathering is transport-limited under thermodynamically saturated conditions (SI $\geq 0$ ), i.e. weathering occurs only when saturated fluids are displaced with incoming unsaturated fluids that can themselves become saturated. Under such chemostatic behavior effluent concentrations do not vary with flow rate (Maher, 2011). In contrast, under strongly under-saturated conditions, assuming sufficient inputs of reactants, e.g. $\mathrm{H}^{+}$, reaction rates remain constant and increasing or decreasing flow rates will decrease or increase effluent concentrations.

These two contrasting conditions are shown by the horizontal and upward concave lines in Fig. 6 which are fitted to pass through the average flow rates and $\mathrm{Na}$ effluent concentrations from the fresh Merced, Panola, and Loch Vale columns. Clearly effluents are not invariant but fall along the curves predicted for fixed reaction rates controlled by flow. Data variability primarily corresponds to flow rate and solute concentration variations, as shown in Figs. 2a and 3. This relationship indicates that $\mathrm{Na}$ is produced primarily from kinetically-controlled weathering of plagioclase which is the silicate furthest from thermodynamic saturation (Fig. 5f).

\section{6 Mineral Contributions to Column Effluents.}

Effluent compositions reflect granitoid mineral abundances and stoichiometry as well as relative reaction rates. A mass balance approach was first employed by Garrels and Mackenzie (1967) to explain stream compositions in granitoid watersheds of Sierra Nevada (USA) and was later modeled using inverse NETPATH model (Plummer et al., 1994). Chemical mass-balance modeling was subsequently used to characterize natural weathering in a number of granitoid watersheds, including Loch Vale (Mast et al., 1990), Rio Icacos (White et al., 1998), and Panola (Bowser and Jones, 2002). In the present NETPATH calculations, the number of elements was set either equal to or one less than the numbers of mineral phases present (mineral abundances and compositions are found in Appendix II.). Primary silicate minerals were allowed only to dissolve and the secondary minerals only to precipitate, as implied by their calculated saturation states (Fig. 5). 
Unique NETPATH outputs for Loch Vale and Panola granitoids were generated by applying six elemental constrains (Na-K-Mg-Ca-Al-Fe) to six mineral phases, i.e., plagioclase, K-feldspar, biotite and calcite and secondary kaolinite and goethite. Hornblende concentrations in these granitoids were low and not entered into the calculations. Effluents were initially 372 dominated by calcite dissolution (positive values at $<1$ yrs in outer plots in Fig. 7 a and b). Over time, more dilute effluents reflected inputs from plagioclase and sub-equal contributions from Kfeldspar (interior plots in Fig. $7 \mathrm{a}$ and b). Aluminum and Si generated during dissolution were incorporated into kaolinite, the precipitation of which gradually declines concurrently with feldspar dissolution (negative losses in Fig 7a and b). Compared to feldspars, biotite dissolution declined over time but remained the primary source of Fe incorporated into secondary goethite.

The modeled Rio Icacos weathering granitoid contains plagioclase, biotite, hornblende 379 and disseminated calcite but essentially no K-feldspar (Fig.7c). Stoichiometric biotite dissolution caused NETPATH to fail due to disproportionally high effluent $\mathrm{K}$ relative to $\mathrm{Na}$ and $\mathrm{Mg}$. Fresh biotite undergoes fast non-stoichiometric oxidation of structural Fe and subsequent release of interlayer K (White and Yee, 1985; Amonette et al., 1988; Taylor et al., 2000), likely explaining the observed excess $\mathrm{K}$ in effluent. Using interlayer biotite $\mathrm{K}$ as separate phase required seven constraints (Na-K-Mg-Ca-Al-Fe-Si) and resulted in a successful NETPATH convergence. After initially large calcite inputs, effluent from the Rio Icacos granitoid becomes dominated by constant inputs of interlayer $\mathrm{K}$ and sub-equal amounts of plagioclase (Fig. 7c).

The modeled Merced granitoid involved the largest number of phases, including plagioclase, K-feldspar, biotite, hornblende, biotite-interlayer-K, calcite, kaolinite and goethite (Fig. 7d). As with the Rio Icacos granitoid, interlayer-biotite-K was required to reproduce high effluent K. A maximum of seven constraints representing major elements measured in the effluents (Na-K-Mg-Ca-Al-Fe-Si) resulted in two possible mineral assemblages differentiated by hornblende/no biotite and biotite/no hornblende. Both phases contained approximately equal proportions $\mathrm{Mg}$ and $\mathrm{Fe}$ and, as such, their contributions were not uniquely defined. A recent $\mathrm{Mg}$ isotope study indicated that biotite initially reacted faster than hornblende (Ryu et al., 2011). Mineral solute contributions shown in Fig 7d (inset) include overlapping biotite and hornblende results. Over time, the interlayer biotite $\mathrm{K}$ loss remained constant, with biotite representing the dominant reactive phase (as with the Rio Icacos quartz diorite, Fig 7c). Loss of interlayer biotite 
$\mathrm{K}$ was accompanied by gradual decreases in plagioclase and $\mathrm{K}$-feldspar dissolution and kaolinite precipitation.

\subsection{Mineral Contributions and ${ }^{87} \mathrm{Sr} /{ }^{86} \mathrm{Sr}$ ratios}

${ }^{87} \mathrm{Sr} /{ }^{86} \mathrm{Sr}$ and $\mathrm{Sr} / \mathrm{Ca}$ ratios have been used to gain insights into relative rates of mineral weathering in granitoid column experiments (Erel et al., 2004; Ganor et al., 2005). While potentially serving as an additional constraint in NETPATH (Plummer et al., 1994), calculations using ${ }^{87} \mathrm{Sr} /{ }^{86} \mathrm{Sr}$ compositions listed Appendix II and Table 5 failed to converge, due to strongly incongruent release of ${ }^{87} \mathrm{Sr} /{ }^{86} \mathrm{Sr}$ (Brantley et al., 1998; Taylor et al., 2000).

When plotted together, changes in fresh granitoid ${ }^{87} \mathrm{Sr} /{ }^{86} \mathrm{Sr}$ and $\mathrm{Sr} / \mathrm{Ca}$ effluent ratios follow a counter clock-wise triangular pathway established for shorter-term data (White et al., 1999; White and Brantley, 2003) (Fig.8a-c). For Merced and Panola, the longer-term solute data presented here (Table 5, and Supplemental Tables) completes the patterns in which the final ${ }^{87} \mathrm{Sr} /{ }^{86} \mathrm{Sr}$ and $\mathrm{Sr} / \mathrm{Ca}$ ratios approximate the initial ratios. The initial solute ratios corresponded most closely to plagioclase, presumably representing rapid dissolution of highly reactive surfaces produced by sample preparation that were quickly exhausted. Over the next days to weeks, $\mathrm{Ca} / \mathrm{Sr}$ ratios generally paralleled mixing lines with calcite, confirming the initial importance of this phase in the NETPATH results (Fig. 7).

After several months of reaction, effluent ${ }^{87} \mathrm{Sr} /{ }^{86} \mathrm{Sr}$ and $\mathrm{Ca} / \mathrm{Sr}$ ratios trended toward higher ${ }^{87} \mathrm{Sr} /{ }^{86} \mathrm{Sr}$, values which are proportional to the age of the granitoids and radiogenic $\mathrm{Sr}$ content of the biotite (note that the biotite $\mathrm{Ca} / \mathrm{Sr}$ ratios were not determined). Finally, over the next several years, effluent ${ }^{87} \mathrm{Sr} /{ }^{86} \mathrm{Sr}$ declined back toward ratios reflecting long-term plagioclase dissolution. This occured for the Merced granitoid in spite of the NETPATH results indicating interlayer K continuing to be the dominant solute source in the column (Fig. 7d). This discrepancy implies that ${ }^{87} \mathrm{Sr}$ produced from the decay of ${ }^{87} \mathrm{Rb}$ substituting for $\mathrm{K}$ in the biotite interlayer is preferentially released early in the experiments. This effect is also dependent on the magnitude of the biotite ${ }^{87} \mathrm{Sr} /{ }^{86} \mathrm{Sr}$ ratios. The final Loch Vale effluent ${ }^{87} \mathrm{Sr} /{ }^{86} \mathrm{Sr}$ ratios remained significantly more radiogenic than plagioclase (Fig 8c) reflecting continued inputs of small amounts of very radiogenic biotite $\mathrm{Sr}$ (note that excess interlayer K was not a required phase; Fig. 7a). 
The initial $\mathrm{Ca} / \mathrm{Sr}$ and ${ }^{87} \mathrm{Sr} /{ }^{86} \mathrm{Sr}$ ratios of the weathered granitoid effluent were similar to 427 their fresh counterparts, reflecting rapid plagioclase dissolution (Fig 8 d-f). However these 428 effluents lacked subsequent $\mathrm{Ca} / \mathrm{Sr}$ increases, indicating calcite loss during previous natural 429 weathering. Rather, effluents moved directly upward to more radiogenic ${ }^{87} \mathrm{Sr} /{ }^{86} \mathrm{Sr}$ ratios. This 430 effect was minor for the weathered Merced granitoid (Fig 8d). However, the maximum ${ }^{87} \mathrm{Sr} /{ }^{86} \mathrm{Sr}$ 431 ratios for the older weathered Panola Granite and Loch Vale granitoids approached those of their 432 unweathered counterparts (Fig. 8e and f). While acetate exchangeable ${ }^{87} \mathrm{Sr} /{ }^{86} \mathrm{Sr}$ from the Merced 433 granitoid was found to be in equilibrium with the final column effluent, exchangeable Sr from 434 the older Panola and Loch Vale granitoids remained much higher, providing an ongoing 435 436 radiogenic source to the effluents. Solute $\mathrm{Ca} / \mathrm{Sr}$ and ${ }^{87} \mathrm{Sr} /{ }^{86} \mathrm{Sr}$ ratios were comparable to plagioclase in the corresponding watersheds (Fig 8d-f) implying that both the reactive calcite and radiogenic biotite components have been removed during natural weathering at this larger scale. differences between experimental and natural silicate weathering rates. A relevant point of departure in this discussion is a plot of experimental and natural plagioclase weathering rates as 443 functions of reaction duration (Fig. 9; after White and Brantley, 2003). Plagioclase is emphasized because it commonly dominates weathering in granitoid rocks and its weathering rate generally is estimated from $\mathrm{Na}$ concentrations in solids and solutes. Figure 9 includes time-dependent plagioclase rates for fresh and weathered granitoids from this study and updated literature rates for previous experimental and field studies (Bandstra et al., 2013; White and Buss, 2014). Values are plotted on a log scale to accommodate the large ranges in the rates and times, which in turn corresponded either to the duration of experimental reaction or to the approximate age of the natural weathering environment.

\section{$451 \quad$ 4.1 Calculation of Column Plagioclase Weathering Rates}

$$
R_{r}=M_{N a} / t \beta S_{A}
$$


455 where $R_{r}$ (moles $\mathrm{m}^{-2} \mathrm{~s}^{-1}$ ) is an empirical rate; more accurately described as a mass flux. It does 456 not correspond directly to an intrinsic plagioclase rate constant as will be subsequently described. $457 M_{N a}$, is the mass of $\mathrm{Na}$ dissolved in effluent and collected in individual sample bottles over a 458 given sampling interval $\mathrm{t}(\mathrm{s}), \beta$ is the stoichiometric coefficient relating the moles of solute $\mathrm{Na}$ 459 per mole of plagioclase (moles mole $\left.{ }^{-1}\right)$, and $\mathrm{S}_{\mathrm{A}}\left(\mathrm{m}^{2} \mathrm{~g}^{-1}\right)$ is the maximum DCB- extracted BET 460 surface area measured at the termination of the experiments (Table 4).

Two-to-five orders of magnitude differences exist between experimental and field weathered plagioclase rates reported from the literature and plotted in Fig. 9 (see data compilation in White and Buss, 2014). Relatively large differences in time frames also exist between individually determined experimental rates and natural weathering environments. In spite of the large uncertainties associated with this diverse dataset, a general relationship of decreasing weathering rates with increasing time is evident (White and Brantley, 2003), described by the empirical regression (diagonal dashed line in Fig 9)

$$
R_{r}=3.47 \times 10^{-13} t^{-0.56}
$$

$$
r^{2}=0.68
$$

471 after $50 \mathrm{yr}$, a 100-fold decrease after $2000 \mathrm{yrs}$, and a 1000-fold decrease after 10,000 kyr etc. A

This power law predicts a 10 -fold decrease in the weathering rate of a silicate mineral comparable power law was previously proposed by Taylor and Blum (1995) to describe the decrease in weathering fluxes from a suite of weathering environments with increasing time. The chemical or physical basis of this apparent continual decrease in reaction rates with time remains controversial. Experimental time spans, even for the present study, do not come close to simulating the long-term aspect of these proposed relationships.

A time-dependent weathering function (Eqn. 2) runs counter to conclusions of many relatively short experimental studies that suggest silicate reaction rates reach steady state. For example, Hausrath et al. (2009) reported that plagioclase weathering in granite column experiments became constant after 40-45 weeks of reaction with unbuffered DI water, a conclusion not supported by present study. Short-term plagioclase dissolution rates, $\mathrm{R}_{\mathrm{r}}$, in both fresh and weathered granitoids, generally fell within the previously reported range (Fig 9). In the 
present study, which exceeded the time spans of previous experimental studies, the fresh granitoid plagioclase weathering rate continued to decline, albeit at progressively slower rates than predicted by the power law (Eqn. 2). After 13.8 yrs. of reaction, the average plagioclase rates were approximately an order of magnitude less than the average of the shorter term literature rates $\left(1.2 \times 10^{-13}\right.$ versus $1.5 \times 10^{-12}$ moles $\left.\mathrm{m}^{-2} \mathrm{~s}^{-1}\right)$.

The question arises as to whether or not extending experimental reaction times, as done in the present study, actually produces closer estimates of state steady-state reactions. If not, the remaining inconsistencies with natural weathering rates could simply be explained by not running experiments long enough, as suggested by the power function (Eqn. 2 and Fig. 9). While log scales (Fig 9) are useful in comparing large ranges in rates and time, they emphasize large changes in reaction rates during the initial stages of the column experiments. Cumulative solute $\mathrm{Na}$ is as linear function of time (Fig 10), demphasizing this effect and reducing the data scatter attributable to short-term sampling effects such as changing flow rates (Figs. 2a).

Initial cumulative solute $\mathrm{Na}$ increases are different for the four granitoids. In particular, the Rio Icacos quartz diorite exhibited relatively large increases (Fig. 10a). However, cumulative outputs became very similar for all the fresh granitoids during the last ten years of reaction, as characterized by linear regression fits (straight lines in Fig. 10), with slopes ranging from 1.22 to $1.32 \mathrm{mmoles} / \mathrm{yr}$. This similarity occured in spite of significant differences in plagioclase compositions ( $\mathrm{An}_{21}$ for Loch Vale to $\mathrm{An}_{50}$ for Rio Icacos granitoids). Plutonic plagioclase is commonly composed of extremely fine intergrown lamellae of albitic and anorthitic compositions. Thus, the more soluble Ca component may become shielded and dependent on the reaction and removal by the less soluble Na phase (White et al. 2008; Maher et al. 2009).

Fits of cumulative solutes with time produced linear regression coefficients $r^{2}>0.94$ for the time period 4.0 to 13.8 years. The distribution of residuals (insets in Fig 10) shows the extent to which cumulative increases deviated from a linear steady state. Random residuals (i.e., for the Merced, Loch Vale, and Rio Icacos granitoids) cluster around zero and lack consistent trends with time. Such distributions are expected for solutes that are primarily dependent on flow rates, which themselves similarly distributed with time (Fig. 2a).

In contrast, the Panola Granite exhibited a consistent convex pattern (Fig. 10b, inset), indicating that variations in the residual distributions were not random and that weathering slowly continued to decline. This trend was previously observed in the shorter-time Panola data 
(White and Brantley, 2003). Except for Panola, steady state weathering appears to have been achieved over the time spans of the experiment. Note however, that these times occupy a very small portion of the entire log time scale shown for the combined experimental-natural rates plotted in Fig. 10.

\subsection{Surface Areas and Reactivities}

Weathering trends with time, whether under experimental or natural conditions, are commonly ascribed to physico-chemical changes in silicate surfaces, either as physical surface areas that are expected to increase due to pitting and etching, or surface reactivity, e.g. the density of reactive sites per unit of surface area, which are expected to diminish with time (Brantley et al. 1999).

The initial $\mathrm{Na}$ decrease in the fresh granitoid effluents ( 1 to 2 orders of magnitude; Fig. 3 ) evidently reflects rapid declines in surface reactivity induced in part by sample preparation, i.e., grinding. The opposing solute increase associated with short-term increases in physical surface area (less than factors of 2 in the first 1.6 years of reaction, Table 4) was negated by these declining reactivities. The lower initial $\mathrm{Na}$ releases from the weathered granitoid counterparts (Fig. 3) reflect lower surface reactivities, presumably due to previous exposure in the natural environment.

The roles of physical surface areas and surface reactivities in controlling solute $\mathrm{Na}$ release becomes less obvious over longer time frames ( $>4$ yrs, Fig. 3). Except for Panola, Na effluents from the fresh granitoids remained essentially constant (Fig.10). Limited BET surface area data (Table 4) suggest that physical surface areas continued to increase, less than doubling over the last decade of reaction. Surface area increases alone should correlate with increases in solute $\mathrm{Na}$, an effect not observed for the fresh granitoids. Near constant release rates (Fig.10) suggests that small increases in physical surface areas were countered by corresponding decreases in surface reactivity over the same time period.

In contrast to the fresh granitoids, solute outputs, including $\mathrm{Na}$, from the weathered granitoids exhibited small increases during the final decade of reaction (Fig. 3). Two previous studies observed solute increases with time under much more acidic conditions. Ganor et al., (2005) reacted hydrothermally-altered granite containing Fe-oxide-coatings at $\mathrm{pH}$ 1. A 
correlation between the mass of Fe dissolved and a factor-of-six increase is Na release with time was attributed to accelerated plagioclase weathering caused by increasing exposure of reactive surfaces as coatings dissolved. The weathered granitoids in our study also contained Fe-oxide and clay coatings (based on visual and SEM observations). However, under the four-order-ofmagnitude higher $\mathrm{pH}$ conditions of the current study, these coatings appear to be more stable. Goethite is supersaturated in output solutes (Fig. 5a) and Fe-containing coatings precipitated near the column inputs of the fresh granitoids. These observations, coupled with low effluent Fe, suggests that removal of Fe-oxide coatings may not effectively increase silicate surface reactivity within a decadal time frame.

Ryu et al. (2011) measured solute increases over time while reacting fresh Precambrian Boulder Creek Granite (similar to the Loch Vale Granite) at $\mathrm{pH}$ 1. The solute trends were attributed to a "sugar lump effect" (Norriel et al, 2009) in which solute rates initally increased as large mineral grains dissaggregated into progressively increasing numbers of smaller particles, thereby increasing total surface areas. No measurements of final surface areas were reported, but a mass-balance model was consistent with a significant (29\%) plagioclase loss (Ryu et al., 2011). While this model may also be applicable to highly porous friable plagioclases present in intensely weathered soils (White et al. 1996), grain dissaggregation in the naturally-weathered granitoids of this study was not observed at column disassembly. The grain size fraction used in the experiments generally consisted of single silicate phases that exhibited sound structural integrity, with only minor pitting and etching. The low mass losses $(<1 \%)$ produced during the present experiment were insufficient to initate dissaggregation.

Surface roughening by itself would be sufficent to produce small surface area increases and therefore increases in weathered column solutes if surface area change dominated over any concurrent decreases in surface reactivity (Fig. 3). In effect this would be the opposite of what occurred in the intial phase of the experiments during which time solute concentrations decreased with time (Fig. 5). Unfortunately, BET surface area data for the weathered granitoids were ambigious due to the presence of high-surface-area hydroxides and clays which were difficult to completely remove by dithionite extraction. As indicated by the converging solute trends (Fig. 3 inserts), lengthening the time of the experiment would have led to comparable solute concentrations suggesting the combined effects of surface area and reactivities would 
575 become equal for the pairs of fresh and weathered granitoids. However, as indicated in Fig. 9,

576 weathering rates of both the fresh and weathered granitoids remained 1 to 3 orders of magnitude

577 higher than natural field rates. This discrepancy is investigated in further detail in the following

578 section.

579

580

581

582

583

584

585

586

587

588

589

590

591

592

593

594

595

596

597

598

599

600

601

602

603

604

\subsection{Direct Comparisons of Experimental and Natural Weathering Rates}

A unique feature of the present study is that the column plagioclase rates can be compared to natural rates previously reported for weathering environments from which the granitoids were obtained (Fig. 9). A detailed discussion of general approaches used to quantify field weathering rates is presented elsewhere (Brantley and White, 2009; White and Buss, 2014).

\subsubsection{Loch Vale}

The Loch Vale field-based plagioclase rates $\left(0.9\right.$ to $3.2 \times 10^{-13}$ moles $\left.\mathrm{m}^{2} \mathrm{~s}^{-1}\right)$ were calculated from solute mass losses (Eqn. 1) in an upland alpine catchment comprised of a pocket veneer of thin soil resting on Precambrian granite (Drever and Clow, 1995). The site was artificially irrigated during two consecutive summers, maintaining soils in a continuously wet condition. Weathering rates during the field experiments were comparable to corresponding column rates reported by Drever and Clow (1995) and observed in the present study (Fig. 10a) but are one to two orders of magnitude faster than those reported for other Pleistocene-glaciated watersheds subjected to natural precipitation (Fig. 9a). This discrepancy suggests that magnitude and timing of accelerated artificial recharge had a significant impact; essentially producing weathering rates in a field setting that were comparable to a laboratory rate determined in the present study.

\subsubsection{Panola}

Plagioclase content increases linearly downward from saprock to fresh bedrock over a six-meter weathering profile within the semi-tropical Panola watershed (White et al., 2001; White et al., 2002). Based on ${ }^{36} \mathrm{Cl}$, the isovolumetric weathering profile is advancing at rate of 7 m per million years (Bierman et al, 1995), establishing the duration of weathering (Figure 9b). Very low initial bedrock permeability, coupled with relatively high recharge, requires that most pore water move downslope along the saprolite-granite interface. 
Loss of highly soluble disseminated calcite serves as a silicate weathering precursor, increasing bedrock permeability sufficiently that transport-limited plagioclase weathering occurs. In contrast, less soluble K-feldspar continues to reflect parent-material abundances, being weathered only at the more-permeable, saprolite-saprock interface. A plagioclase rate of $2 \times 10^{-16}$ moles $\mathrm{m}^{2} \mathrm{~s}^{-1}$ resulted from fitting a spreadsheet model to the bedrock plagioclase weathering profile (White et al., 2001). This rate is comparable to that for other older weathering environments (data points along the time line in Fig. 9b) and is about three orders of magnitude slower than the Panola plagioclase column rates of this study (Fig 10b), which reacted far from thermodynamic saturation (Fig. 5f).

\subsubsection{Rio Icacos}

In the tropical Rio Icacos watershed in Puerto Rico, isovolumetric plagioclase weathering occurs beneath a thick saprolite regolith (White et al., 1998). Unlike Panola, plagioclase losses here are confined to near the bedrock surface within a series of thin concentric "onion-skin" rindlets bounded within thicker fracture blocks (Fletcher et al., 2006; Buss et al., 2005; 2008). Interstitial porosity is first created from weathering of altered calcic cores of plagioclase and apatite inclusions. Porosity is then expanded by strain and fracture propagation produced through oxidation and expansion of biotite (Buss et al., 2008). This reaction also releases $\mathrm{K}$ and radiogenic Sr from biotite (Petite-Ridge et al, 2009), as demonstrated by NETPATH simulations (Fig. 7c). In a very rapid steady-state denudation in a tropical climate, the Rio Icacos weathering front propagates through a meter of rindlets in about $10^{4} \mathrm{yrs}$, based on ${ }^{10} \mathrm{Be}$ estimates of Brown et al. (1995).

An average plagioclase weathering rate of $3 \times 10^{-15}$ moles $\mathrm{m}^{-2} \mathrm{~s}^{-1}$ was first calculated from solid state $\mathrm{Na}$ losses across sets of rindlets (Turner et al., 2003). This rate is an order of magnitude slower than for bedrock weathering at Panola but falls along the time line in Figure 9c. In contrast, a significantly faster rate $\left(1.1 \times 10^{-13}\right.$ moles $\left.\mathrm{m}^{2} \mathrm{~s}^{-1}\right)$, equivalent to the Rio Icacos column experiment (Fig. 10c), was subsequently determined using a simplified geometric fit to rindlets' mineral abundances at a different watershed location (Buss et al. 2008). While plagioclase was completely depleted in the rindlet interiors of this study, only partially depleted plagioclase was observed in the Turner et al. (2003) study. These differences are attributed to the 
highly heterogeneous nature of fracture flow and corresponding large differences in the extent of thermodynamic saturation.

\subsubsection{Merced Soils}

The Merced column experiments most closely approximate weathering resulting from vertical percolation of pore water through the sandy sediments of the Merced soil chronosequence. Physical, hydrologic and mineralogic characterisitics of the fresh Merced granitoid are compared to the relatively unweathered deep horizon (5.5 m) of $250 \mathrm{ka}$ Riverbank soil in Table 3. Similarities include plagioclase concentrations, soil porosities and laboratorymeasured saturated hydraulic conductivities and mineral surface areas.

The sandy sediments of the Merced soil chronosequence were derived primarily from granitoids in the Merced River and Toulumne River drainages in the Sierra Nevada Mountains of central California, including the granodiorite of Arch Rock from Yosemite (Table 2). These soils are up to ten meters thick and range in age from $10 \mathrm{kyr}$ to $3000 \mathrm{kyr}$. Total mass losses calculated for specific soil horizons and coupled to BET surface area measurements suggest declining plagioclase rates with increasing soil age (from 8.1 to $0.5 \times 10^{-16}$ moles $\mathrm{m}^{-2} \mathrm{~s}^{-1}$; White et al, 1996). These rates are orders of magnitude slower than for the fresh Merced column $\left(1.2 \times 10^{-13}\right.$ moles $\mathrm{m}^{-2} \mathrm{~s}^{-1}$ ) but fall along the time-dependent weathering line in Fig. 9d. Natural weathering rates ( 3 to $7 \times 10^{-16}$ moles $\mathrm{m}^{-2} \mathrm{~s}^{-1}$ ) were calculated in a subsequent study based on solute $\mathrm{Na}$ fluxes, recharge inputs, evapotranspiration, and pore water residence times (White et al., 2005b). Comparable rates imply that present day weathering rates were stable over very long times at Merced.

\subsection{Effects of Pore Water Velocity}

Aside from time, the biggest difference between column and natural soil weathering is rate and composition of pore water flow (Table 3). The column pore waters were fluid-saturated as imposed by a upward flow direction while the Riverbank soil is generally unsaturated due to low recharge and gravitational drainage (White et al., 2005b). Corresponding pore water residence times are about ten days in the Merced column versus more than a year in a comparable meter of soil. 
We used the CrunchFlow reactive transport model to investigate the role of fluid flow rates in bridging the large differences in experimental and natural weathering rates of the Merced granitoid (Fig. 9d). As described in the methods section, parameters for our CrunchFlow simulations were modified from parameters used for a similar chronosequence weathering environment near Santa Cruz, CA (Maher et al., 2009; Lawerence et al., 2014) and those based on the FLOWTRAN Merced soil weathering simulations (Moore et al., 2012).

We simulated the influence of variable fluid (Darcy) velocities, ranging from the experimental flow $\left(\mathrm{q}_{\exp }=160 \mathrm{~m} \mathrm{yr}^{-1}\right)$ to the much slower rates representative of natural field conditions $\left(\mathrm{q}_{\text {field }}=0.6 \mathrm{~m} \mathrm{yr}^{-1}\right.$; Table 3$)$ on plagioclase saturation and reaction rate (Fig. 11a and b). The flow rates at field conditions were estimated by the net difference between average rainfall and evapotransition based on $\mathrm{Cl}$ mass balance (White et al., 2005b). Flow effects were investigated using both the transition state theory (TST) rate law, employing only a far-fromequilibrium rate constant (FFE), and the parallel rate law (PRL), employing both a FFE and a close-to-equilirum rate (CTE) (Maher et al., 2009; Lawrence et al., 2014). In both cases, the FFE rate was set equal to the experimental plagioclase rate for the fresh Merced column, while the CTE rate constant for plagioclase dissolution was taken from Maher et al. (2009).

Although measured only in column discharge, porewater solutes cumulatively increased with increasing reaction and fluid residence times within the columns in a manner similar to that observed for pore waters measured at various depths in the Merced soils. For comparison, saturation-versus-flow and rate-versus-flow relations for column nodes near the inlet and outlet $(0.05$ and $0.95 \mathrm{~m})$ are shown in Fig. 11a and b. Assuming that a steady state reaction rate is achieved after 4 years (Fig 10d), the relationships shown in Fig. 11 will remain constant with time. This condition is only applicable to CrunchFlow simulations over relatively short time spans (like those of the column experiments) during which negligible changes in reactive mineral masses and surface areas occur.

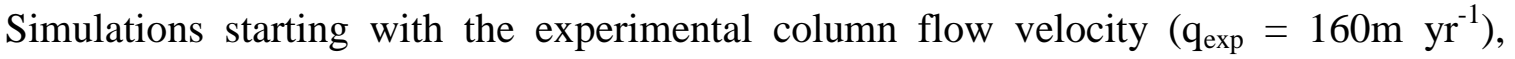
produced highly unsaturated conditions under both the TST and PRL scenarios (Fig. 11a). As expected, effluent concentrations for the model node corresponding to the column inlet was thermodynamically less saturated than at the distal node. In this case, the plagioclase saturation index $\left(\mathrm{SI} \approx 10^{-12}\right)$ was consistent with the SI values previously calculated from effluent outputs 
(Fig. 5f). Both the TST and PRL simulations reproduced the experimental plagioclase rate (Fig. 11b) indicating weathering was kinetically-limited and not dependent on transport distance or time, a conclusion previously shown by the effluent concentration-flow rate relationships (Fig. $6)$.

The SI values increased as the modeled flows were progressively decreased (Fig. 11a). However, reaction affinities remained sufficiently negative such that the TST and PRL simulations continued to return the same far-from-equilibrium rate constant (Fig. 11b). Only after flow rates were reduced below $\sim 1 \%$ of $\mathrm{q}_{\exp }$ were close-to-saturation conditions approached (Fig. 11a). While not significantly impacting rates near the column inlet, decreased flow resulted in the onset of transport limiting reaction at the distal node (Fig. 11b). The linearity of the TST formulation resulted in a rapid approach to saturation with further flow decreases, leading to a precipitous drop in the reaction rate.

At a flow rate of $0.1 \%$ of $\mathrm{q}_{\exp }\left(0.12 \mathrm{~m} \mathrm{yr}^{-1}\right)$, CrunchFlow results predicted a distal reaction rate comparable to that calculated from the solute fluxes under Merced field conditions ( 3 to $7 \mathrm{x}$ $10^{-16} \mathrm{~mol} \mathrm{~m}^{-2} \mathrm{~s}^{-1}$ at $0.06 \mathrm{~m} \mathrm{yr}^{-1}$ ). At even slower flow rates, the porewaters became fully saturated and plagioclase dissolution approached zero. The corresponding PRL simulation produced a more dampened approach to saturation due to the previously described plateauing interaction between the CTE and FFE rate constants (Burch et al., 1993; Hellmann and Tisserand, 2006). Even for flow rates significantly less than Merced field values, plagioclase thermodynamic saturation is never completely achieved. As discussed by Maher et al. (2009) and Moore et al. (2013), near- equilibrium conditions also reflect competing kinetics of kaolinite precipitation, which were included in CrunchFlow but not investigated in detail.

Simulations which decreased column flow rates to within the range of deep percolation rates measured in the Merced soils were capable of approximating natural weathering rates (Fig. 11b). Most natural plagioclase rates are significantly slower than laboratory rates suggesting the predominance of transported-limited weathering. However, large differences in natural profiles occur. Major discrepancies in the plagioclase rates of Turner et al. (2008) and Buss et al. (2013) at Rio Icacos may be related to the highly heterogeneous fracture flow and differences in transport and kinetic limitations (Fig. 9c). These conditions are contrasted to the more homogeneous, albeit slow, matrix flow occurring in the Panola regolith. This latter condition 
produced very old and deeply weathered profiles, with highly depth dependent zones of weathered primary minerals (Fig 9b). Using CrunchFlow simulations, Maher (2011) concluded that differences in solute discharge fluctuations in small watersheds are also related to differences in fluid flow and transport (chemostatic) or kinetic controls. The rapid weathering rate in the Loch Vale catchment study (Clow and Drever, 1996) may be related to artificial irrigation, which favored the shift to kinetic-controlled weathering comparable to experimental conditions (Fig. 9a).

\subsection{Long-term Weathering Simulations}

Despite some success projecting experimental column data to natural soil flow rates for approximating corresponding natural reaction rates over short time intervals, the extrapolation to much longer time intervals for natural weathering was less successful. As an example of longterm weathering, the $250 \mathrm{kyr}$ Merced Riverbank soil (Table 3) is described in terms of fraction of residual plagioclase remaining relative to initial concentrations (Fig. 11c). The Riverbank soil plagioclase values were adjusted for total mass losses in addition to physical compaction and dilation using quartz as a conservative component (see White et al., 1996 and Moore et al., 2012, for detailed discussion of mineral distributions at Merced).

As a baseline simulation, we parameterized CrunchFlow using the estimated natural pore water flow rate (White et al., 2002), a FFE rate constant equivalent to the experimental reaction rate from this study (Fig. 10d), and other CrunchFlow parameters listed in Table 6. The baseline predicted residual soil plagioclase distributions were significantly depleted relative to observations. Over-estimation of long-term weathering for the Santa Cruz and Merced soils using baseline simulations was previously noted (White et al., 2008, Maher et al., 2009 and Moore et al., 2012). A much closer fit to the observed Merced soil plagioclase distribution using the PRL model was obtained (Fig. 11c) using the fitted parameters in Table 7. This required decreasing the FFE plagioclase dissolution rate (initially equivalent to the experimental rate; Table 7) by a factor of ten, with corresponding smaller decreases in the CTE and kaolinite rates as initially established by Maher et al. (2009). These adjustments are comparable to a previous simulation of the Riverbank soil using the reactive transport code FLOWTRAN (Moore et al., 2012), which required decreasing the reactive surface area parameters by a factor of fifty (note the relationship between reaction rate and surface area in Eqn. 1). 
While extrapolating column flow rates to field estimated flow approximated natural weathering rates over short timescales (Fig. 11b), a further decrease in field flows (from 0.060 to $0.0054 \mathrm{~m} \mathrm{yr}^{-1}$; Table 7) was required to simulate the long-term weathering profile (Fig. 11c). The simulated flow $\left(0.0054 \mathrm{~m} \mathrm{yr}^{-1}\right)$ rate was also slower than estimated flow rate of $0.016 \mathrm{~m} \mathrm{yr}^{-1} \mathrm{used}$ in the best fit FLOWTRAN simulation for the Riverbank soil (Moore et al. 2012). This order-ofmagnitude decrease was a significantly different from pore-water net-flow field estimates (White et al., 2005b) based on the difference between average rainfall and evapotranspiration based on $\mathrm{Cl}$ balances. Although climate information inclusive of the age span of the Merced soils (240 kyr) does not exist, shorter-term evidence covering the last $20 \mathrm{kyr}$ do not suggest past drier conditions that would be reflected in lower recharge (Street et al., 2012).

The discrepancy more likely relates to the physical nature of pore water flow and the method by which it is estimated. Column tracer tests documented near-ideal break-through curves indicating homogenous flow (Fig. 2c). However, heterogeneous pore water flow is ubiquitous in soils as evidenced by bromide tracer tests indicating uptake of pore waters into dead end pore spaces in the Merced soils (Green et al., 2005). In contrast, soil pits documented progressive development of vertical conduits in argillic horizons, which transmit pore water relatively rapidly (White et al., 2005b). This more active flow is preferentially measured in pore water samples along with lower $\mathrm{Cl}$ concentrations, reflecting less total evapotranspiration.

In addition, the rate of pore water flow is strongly dependent on the extent of fluid saturation. Semi-arid conditions at Merced are reflected in average field saturation of about $70 \%$ for the Riverbank soil (White et al., 2005b). However, this value varies widely, particularly at relatively shallow depths due to the strong seasonality in rainfall (White et al. 2005b). An experimental Riverbank soil study by Stonestrom et al. (1998) indicated that small decreases in moisture produced exponential decreases in unsaturated hydrologic conductivities, implying that pore waters were essentially immobile except during seasonal wetting. Fluid stagnation under dry conditions is expected to increase thermodynamic saturation and decrease reaction rates, as suggested by column experiments. Evans and Banwart (2006) found a factor of four decrease in mineral dissolution rates in unsaturated columns compared to saturated conditions. The role of secondary surface effects is also suggested by Ganor et al. (2005), who documented decreased reaction rates after drying of plagioclase surfaces for extended times. The combined results of 
CrunchFlow in this study and the FLOWTRAN simulations of Moore et al. (2012) emphasize the inhibitory role of external factors controlling weathering rates under field conditions. In both cases, the intrinsic rate constants derived from laboratory studies result in over-prediction of plagioclase dissolution compared to field observations. This is compensated by reducing the reactive surface area of the weathering minerals and/or by reducing the long-term flow velocity.

\section{CONCLUSIONS}

Natural granitoid weathering is complex and inherently heterogeneous, with different minerals weathering at different rates. This problem is accentuated in experimental studies due to rapid reactions of more soluble trace components, normally exhausted during the early stages of natural weathering. Uncertainties also exist as to whether major mineral phases achieve steady state reaction rates during short experimental reaction times due to gradual changes in surface reactivity. Additionally, differences in fluid flow dynamics and rates and of experimental and natural systems can profoundly affect mineral surface availability and the extent to which minerals approach thermodynamic saturation. These issues are addressed in this study using pairs of fresh and partially naturally weathered granitoids reacted in flow-through columns under ambient conditions. This study is unique in terms of the decadal scale of the experiments and in the direct comparison to previously determined natural weathering rates for the same granitoids.

Miscible displacement experiments at the end of the study revealed nearly uniform piston-like flow with little tailing, implying very narrow distributions of pore-water residence times. These conditions are contrasted to previous column studies which invoked dual permeability and stagnant pore spaces to explain apparently slower dissolution rates in columns compared to well-stirred batch dissolution experiments.

Total mineral mass losses from both fresh and weathered granitoids, based on total solute discharge, were less than one percent of total mass over nearly 14 years of reaction. This is consistent with a general lack of surface dissolution features and only small BET surface area increases after dithionite (DCB) extraction. Pre-DCB treated surface areas were significantly higher due to the precipitation of secondary Fe-oxyhydroxides, the only secondary phase positively identified as forming in the columns. 
Initial higher effluent concentrations from the fresh versus weathered granitoids, are 813 attributed to rapid reaction of fresh surfaces and unstable trace minerals. Over decadal time 814 frames, solute trends converged, with fresh granitoid solute rates decreasing linearly with time 815 and weathered granitoid release rates increasing slightly, associated with measured dissolution of 816 naturally formed protective surface coatings. These relatively small changes (less than a factor of 817 2) indicated that minerals producing these solutes had not achieved but are approaching steady 818 state reaction rates after nearly 14 years. The results contrast with previous studies, which made 819 the case for steady-state conditions after much shorter reaction times. minerals and possibly heterogeneous reactivities, as supported by NETPATH mass-balance calculations. Calcium and Sr release were dominated by early dissolution of disseminated calcite, 823 which diminished with time leading to eventual dominant control by plagioclase. High initial solute $\mathrm{K}$ from interlayer biotite represented a reaction that continued to dominate in some fresh granitoids, while others reflected proportionally greater inputs from K-feldspar. Sequential reactions, as verified by ${ }^{87} \mathrm{Sr} /{ }^{86} \mathrm{Sr}$ ratios, were of the order: surface-perturbed plagioclase $\rightarrow$ trace calcite dissolution $\rightarrow$ biotite oxidation $\rightarrow$ bulk plagioclase dissolution. While possibly present in some very young natural weathering environments, the complete sequence was not observed for any of the weathered granitoids used in this study.

Only Na release truly approached steady-state by the end of the experiment, reflecting the fact that plagioclase was the sole source of $\mathrm{Na}$. Interestingly, $\mathrm{Na}$ release was very similar for all 832 the granitoids in spite of significantly differing stoichiometries $\left(\mathrm{An}_{21}\right.$ to $\left.\mathrm{An}_{50}\right)$. This result supports micro-texture shielding of the more reactive calcic component.

Plagioclase reaction rates were about an order of magnitude slower than reported for shorter-term experiments. This implies that assumptions of steady-state conditions in previous column studies failed to account for the very gradual declines in surface reactivity that occur over longer time frames. The duration of this study is still very short compared to natural weathering. Extending reaction times by additional orders of magntiude, although experimentally implausible, could potentially produce further downward rate adjustments and further bridge the differences between experimental and natural reaction rates. 
In addition to reaction time, fluid flow rates represent the largest difference between experimental and natural weathering for the granitoids used in this study. Much faster column flow produced highly unsaturated thermodynamic conditions for plagioclase and other major primary silicates. This resulted in kinetic controlled dissolution during which small increases or decreases in flow produced reciprocal changes in effluent concentrations. This is contrasted to transport-limited chemostatic weathering observed in most natural environments, where themodynamically saturated fluids are slowly displaced by incoming unsaturated fluids which themselves become saturated. Under these conditions, effluent concentrations do not vary with fluid flow rate.

The significant difference between fast mineral weathering rates under kinetically controlled experimental conditions and transport-limited natural weathering was examined using a reactive transport model in which measured experimental flow rates were progressively decreased to those reproducing natural flow. Baseline simulations over relatively short experimental time scales reproduced the progressive thermodynamic saturation and declining reaction rates observed in the natural environment. However, extending these simulations to the duration of natural weathering still resulted in significant discrepancies between predicted and observed solid-state weathering profiles. Approximating the observed mineral profiles required moderate decreases in intrinsic reaction rates for primary plagioclase and $\mathrm{K}$-feldspar and for kaolinite precipitation. The attendant need for large decreases in fluid flow rates suggests that, unlike the column experiments, fluid flow and exposure to reactive mineral surfaces is significantly limited in natural environments.

\section{ACKNOWLEDGMENTS}

The authors thank U. S. Geological survey colleagues Tom Bullen and John Fitzpatrick for Sr isotope data and David Clow for the Loch Vale granitoid samples. Kate Maher of Stanford University provided insights into CrunchFlow modeling. We especially acknowledge our or coauthor, colleague, and dear friend Davison Vivit, who succumbed to cancer, for his insights and analytical skills which were critical for this study. This work was funded through the Climate and Land-use Change and National Research Programs of the USGS. We thank Kate Campbell, USGS, Boulder, CO and 3 anonymous reviewers for helpful comments and insights. Use of trade names is for identification purposes only. 
873

874

875

876

877

878

879

880

881

882

883

884

885

886

887

888

889

890

891

892

893

894

895

896

897

898

899

900

901

902

903

904

905

906

907

908

909

910

911

912

913

914

915
Afifi, A.A., Bricker, O.P. and Chemerys, J.C. (1985) Experimental chemical weathering of various bedrock types at different $\mathrm{pH}$-values. Chemical Geology 49, 87-113.

Amonette, J., Ismail, F.T. and Scott, A.D. (1988) Oxidation of biotite by different oxidizing solutions at room temperature. Soil Science. America. J. 49, 772-777.

Anderson, S.P., Drever, J.I. and Humphrey, N.F. (1997) Chemical weathering in glacial enviroments. Geology 25, 399-402.

Anderson, M. B., Y. Erel, ad Bourdon, B.(2009) Experimental evidence for ${ }^{234} \mathrm{U}_{-}{ }^{238} \mathrm{U}$ fractionation during granite weathering with implications for ${ }^{234} \mathrm{U}_{-}^{238} \mathrm{U}$ in natural waters. Geochimica et Cosmochimica Acta 73,4124-4141.

Bandstra, J., Buss, H.L., Campen, R.K., Liermann, L.J., Moore, J., Hausrath, E.M., NarvarreSitchler, A.K., Jang, J. and Brantley, S.L. (2008) Appendix: Compilation of Mineral Dissolution Rates, in: Brantley, S.L., Kubiciki, J.D., White, A. (Eds.), Kinetics of WaterRock Interaction. Springer, pp. 737-824.

Bierman P., Gillespie A., Caffee M., and Elmore D. (1995) Estimating erosion rates and exposure ages with ${ }^{36} \mathrm{Cl}$ produced by neutron activation. Geochimica Cosmochimica Acta 59, 3779-3798.

Blum, A.E. (1994) Feldspars in weathering, in: Parson, I. (Ed.), Feldspars and their reactions. Kluwer Academic Press, Netherlands, pp. 595-629.

Blum, J.D., Erel, Y. and Brown, K. (1994) ${ }^{87} \mathrm{Sr} /{ }^{86} \mathrm{Sr}$ ratios of Sierra Nevada stream waters: Implications for relative mineral weathering rates. Geochimica Cosmochimica Acta 58, 5019-5024.

Bowser, C.J. and Jones, B.J. (2002) Mineralogical controls on the composition of natural waters dominated by silicate hydrolysis. American J. Science 302, 582-662.

Brantley, S.L. (2004) Mineral dissolution kinetics, in: Drever, J.I. (Ed.), Surface and Ground Water, Weathering, Erosion and Soils. Elsevier, Amsterdam.

Brantley, S.L. and White, A.F. (2009) Approaches to Modeling Regolith, in: Oelkers, E.H. (Ed.), Water-Rock Interaction. Mineralogical Society of America.

Brantley, S.L., Chesley, J.T. and Stillings, L.L. (1998) Isotopic ratios and release rates of strontium measured from weathering of feldspars. Geochimica Cosmochimica Acta 62, 1493-1500.

Brantley, S. L., White, A. F. and Hodson, M. (1999) Specific surface area of primary silicates. In Growth and Dissolution in Geosystems eds. B Jamtveit and P. Meakini. Kluwer Academic, Dordrecht, Boston, pp 291-326.

Brown, E.T., Stallard, R.F., Larsen, M.C., Raisbeck, G.M. and Yiou, F. (1995) Denudation rates determined from the accumulation of in situ produced ${ }^{10} \mathrm{Be}$ in the Luquillo Experimental Forest, Puerto Rico. Earth Planetary Sciences Letters 129, 193-202.

Bullen, T., White, A. F., Blum, A. Harden, J. and Schulz, M. (1997) Chemical weathering of a soil chronosequence on granitoid alluvium: II. Mineralogic and isotopic constraints on the behavior of strontium. Geochimica Cosmochimica Acta 61, 291-306.

Bullen, T.D., White, A.F., Huntington, T.G. and Peters, N.E. (1999) A new approach for determining the ${ }^{87} \mathrm{Sr} /{ }^{86} \mathrm{Sr}$ ratio of the "granitoid" weathering component, in: Armannsson, H. (Ed.), Geocemistry of the Earth's Surface. A. A. Balkema, Reykjavik, Iceland, pp. 369-372. 
Burch, T.E., Nagy, K.L. and Lasaga, A.C. (1993) Free energy dependence of albite dissolution kinetics at $80^{\circ} \mathrm{C}$, and $\mathrm{pH}$ 8.8. Chemical Geology. 105, 137-162.

Buss, H.L., Bruns, M.A., Schulz, M.S., Moore, J., Mathur, C.F. and Brantley, S.L. (2005) The coupling of biologic iron cycling and mineral weathering during saprolite formation , Luquillo Mountains, Puerto Rico. Geobiology 3, 247 -260.

Buss, H.L., Sak, P.B., Webb, S.M. and Brantley, S.L. (2008) Weathering of the Rio Blanco quartz diorite, Luquillo Mountains, Puerto Rico: Coupling oxidation, dissolution and fracturing. Geochimica Cosmochimica Acta 72, 4488-4507.

Calkins, F.C., Huber, N.K. and Roller, J.A. (1985) Bedrock geologic map of Yosemite Valley, Yosemite National Park, California. U. S. Geol.. Survey Misc. Invest. Ser. Maps I-1639.

Chapman, J.B., Dominik, J.B., Weiss, J., Shan, Y. and Lemburget, M. (2009) Iron isotope fractionation during leaching of granite and basalt by hydrochloric and oxalic acids. Geochimica et Cosmochimica Acta 73, 1312-1324.

Clow, D.W. and Drever, J.I. (1996) Weathering rates as a function of flow through an alpine soil. Chemical Geology 132, 131-141.

Clow, D.W., M.A., M., Bullen, T.D. and Turk, J.T. (1997) Strontium 87/strontium 86 as a tracer of mineral weathering reactions and calcium sources in an alpine/subalpine watershed, Loch Vale, Colorado. Water Resources Research 33, 1335-1351.

Cole, J.C. (1977) Geology of east-central Rocky Mountain National Park and vicinity with emphasis on the emplacement of the Precambian Silver Plume Granite in the Longs Peak-St Vrain Batholith. Ph.D dissertation University of Colo., Boulder, 1977, 256p.

Dixon, J.C., Thorn, C.E., Darmody, R.G. and Schlyter, P. (2001) Weathering rates of fine pebbles at the soil surface in Karkevagge, Swedish Lapland. Catena 45, 273-286.

Drever, J.I. and Clow, D.W. (1995) Weathering Rates in Catchments, in: White, A.F., Brantley, S.L. (Eds.), Chemical Weathering Rates of Silicate Minerals. Mineral. Soc. Amer., pp. 463-481.

Driscoll, C.T., van Breemen, N. and Mulder, J. (1985) Aluminum chemistry in a forested spodosol. Soil Science. Society. America. J. 49, 437-444.

Erel, Y., Blum, J.D., Roueff, E. and Ganor, J. (2004) Lead and Strontium isotopes as monitors of experimental granitoid mineral dissolution. Geochimica Cosmochimica Acta 68, 46494663.

Evans, K.A., and Banwart, S. A. (2006) Rate controls on the chemical weathering of natural polymineralic material I. Dissolution behavior of polymineralic assemblages determined using both saturated and unsaturated column experiments. Applied Geochemistry 21, 352-376.

Fletcher, R.C., Buss, H.L. and Brantley, S.L. (2006) A spheroidal weathering model coupling porewater chemistry to soil thickness during steady state denudation. Earth Planetary Science 244,444-457.

Fritz, S.J. (1988) A comparative study of gabbro and granite weathering. Chemical Geology 68, 275-290.

Ganor, J., Roueff, E., Erel, Y. and Blum, J.D. (2005) The dissolution kinetics of a granite and its minerals- Implications for comparison between laboratory and field dissolution rates. Geochimcia et Cosmochimica Acta 69, 602-621. 
Garrels, R.M. and Mackenzie, F.T. (1967) Origin of the chemical composition of some springs and lakes, in: Stumm, W. (Ed.), Equilibrium concepts in natural water systems, Advances. In Chemistry Series, American Chemical. Society,12, 222-242.

Gautier, J.M., Oelkas, E.H. and Schott, J. (2001) Are quartz dissolution rates proportional to B.E.T. surface areas? Geochimica et Cosmochimica Acta 65, 1059-1070.

Green, C.T., Stonestrom, D.A., Bekins, B.A. and Akstin, K.C. (2005) Measured versus predicted recharge and transport through a sandy soil in the San Joaquin Valley, California. Water Resources Research 41, W10414.

Haggerty, R., Harvey, C.F., von Schwerin, C.F., and Meigs, L.C. (2004) What controls the apparent timescale of solute mass transfer in aquifers and soils? A comparison of experimental results. Water Resources Research 40, W01510.

Harden, J.W. (1987) Soils developed in granitic alluvium near Merced, California. U.S. Geological Survey Bulletin 1590-A, 104.

Harlavan, Y., Erel, Y. and Blum, J.D. (1998) Systematic changes in lead isotopic composition with soil age in glacial granitic terrains. Geochimica Cosmochimica Acta 62, 33-46.

Hausrath, E.M., Neaman, A. and Brantley, S.L. (2009) Elemental release rates from dissolving basalt and granite with and without organic ligands. American. Journal of Science. 309, 633-660.

Helgeson, H.C., Murphy, W.M. and Aagard, P. (1984) Thermodynamic and kinetic constraints on reaction rates among minerals and aqueous solutions, II. Rate constants, effective surface area, and the hydrolysis of feldspar. Geochimica. Cosmochimica Acta 48, 24052432.

Hellmann, R. and Tisserand, D. (2006) Dissolution kinetics as a function of the Gibbs free energy of reaction: An experimental study based on albite feldspar. Geochimica Cosmochimica Acta 38370, 364-383.

Higgins, M.W., Atkins, R.L., Crawford, T.J., Crawford, R.F., III, Brooks, R. and Cook, R. (1988) The structure, stratigraphy, tectonostratigraphy and evolution of the southern most part of the Appalachian orogen. U. S. Geological Survey Professional. Paper 1475, 173.

Hodson, M.E. (2003) The influence of Fe-rich coatings on the dissolution of anorthite at pH 2.6. Geochimica Cosmochimica Acta 67, 3355-3363.

Klute, A. and Dirksen, C. (1986) Hydraulic conductivity and diffusivity: laboratory methods, in: Klute, A. (Ed.), Methods of Soil Analysis. Soil Sci Soc America, Madison, WI, pp. 687699.

James, R.V., and Rubin, J. (1972) Accounting for apparatus induced dispersion in analysis of miscible displacement experiments. Water Resources Research 8, 717-721.

Lawrence, C., Harden, J. and Maher, K. (2014) Modeling the influence of organic acids on soil weathering. Geochimica et Cosmochimica Acta 139, 487-507.

Lichtner, P.C. (1988) The quasi stationary state approximation to coupled mass transport and fluid-rock interaction in a porous medium. Geochimcia et Cosmochimica Acta 52, 143165.

Likens, G.E. and Bormann, F.H. (1974) Acid Rain: A serious regional environmental problem. Science 188, 1176-1179.

Lowell, L.A. (1967) Sodium-citrate-dithionite of biotite. Soil Science 103, 101-109.

Maher, K. (2010) The dependence of chemical weathering rates on fluid residence time. Earth and Planetary Science Letters 294, 101-110. 
Maher, K. (2011) The role of fluid residence time and topographic scales in determining chemical fluxes from landscapes. Earth and Planetary Science Letters 312, 48-58.

Maher, K., Steefel, C.I. and White, A.F. (2009) The role of reaction affinity and secondary minerals in regulating chemical weathering rates at the Santa Cruz marine terrace chronosequence, California. Geochimica et Cosmochimica Acta 73, 2804-2831.

Mast, M.A., Drever, J.I. and Barron, J. (1990) Chemical weathering in the Loch Vale watershed, Rocky Mountain National Park, Colorado. Water Resources Research 26, 2971-2978.

Moore, J., Lichtner, P.C., White, A.F. and Brantley, S.L. (2012) Using a reactive transport model to elucidate differences between laboratory and field dissolution rates in regolith. Geochimica Cosmochimica Acta 93, 235-261

Neaman, A., Chorover, J. and Branley, S.L. (2006) Effects of Organic acids on granite dissolution in batch experiments. American Journal of Science. 306, 451-473.

Noiriel C., Luquot L., Made’ B., Raimbault L. and Gouze P. (2009) Changes in reactive surface area during limestone dissolution: an experimental and modeling study. Chem. Geol. 265, $160-170$.

Nugent, M.A., Brantley, S.L., Pantano, C.G. and Maurice, P.A. (1998) The influence of natural mineral coatings on feldspar weathering. Nature 396, 527-622.

Parkhurst, D.L. and Appelo, C.A.J. (1999) User's guide to PHREEQC (version 2)-A computer program for the speciation, batch-reaction, one dimensional transport, and inverse geochemical calculations. U. S. Geological. Survey. Water Resources Investigation Report 99-4259, 299p.

Pett-Ridge, J.C., Derry, L.A. and Barrows, J.K. (2009) Ca/Sr and ${ }^{87} \mathrm{Sr} /{ }^{86} \mathrm{Sr}$ ratios as tracers of Ca and $\mathrm{Sr}$ in the Rio Icacos watershed, Luquillo Mountains, Puerto Rico. Chemical Geology 267, 32-45.

Piotr, M. and Thomasb, M.F. (2002) The interpretation and significance of weathering mantels. Catena 49, 5-24.

Plummer, L.N., Prestemom, E.C. and Parkhurst, D.L. (1994) An interactive code (NETPATH) for modeling NET geochemical reactions along a flow path. U. S. Geological. Survey. Water Resources Investigation Report 94-4169.

Price, J.R., Vebel, M.L. and Patino, L.C. (2005) Allanite and epidote weathering at the Coweeta hydrologic laboratory, western North Carolina, U.S.A. American Mineralogist 90, 101114.

Rivas, T., Prieto, B., Siliva, B. and Birgine, J.M. (2003) Weathering of grantic rocks by chloride: effects of the nature of the solution on weathering morphology. Earth Surface Processes and Landforms 28, 425-436.

Ryu, J., Jacobson, A., Holmden, C., Lundstrom, C. and Zhang, Z. (2011) The major ion, $\delta^{44 / 40} \mathrm{Ca}$, $\delta^{44 / 42} \mathrm{Ca}$, and $\delta^{26 / 24} \mathrm{Mg}$ geochemistry of granite weathering at $\mathrm{pH}=1$ and $\mathrm{T}=25^{\circ} \mathrm{C}$ : power-law processes and the relative reactivity of minerals. Geochimica Cosmochimica Acta 75, 6004-6026.

Schnoor, J.L. (1990) Kinetics of chemical weathering: A comparsion of laboratory and field rates, in: Stumm, W. (Ed.), Aquatic Chemical Kinetics. J. Wiley and Sons, pp. 475-504.

Seiders, V.M. (1971) Cretaceous and lower Tertiary stratigraphy of the Gurabo and El Yunque Quadrangles, Puerto Rico. U. S. Geological Survey Bulletin 1294-F, 1-53.

Steefel, C.I. and Yabusaki, S.B. (1996) OS3D/GIMRT, Software for multicomponentmultidimensional reactive transport: User's manual and programer's guide. PNNL Report 1166, 56. 
1077

1078

1079

1080

1081

1082

1083

1084

1085

1086

1087

1088

1089

1090

1091

1092

1093

1094

1095

Stonestrom, D.A., White, A.F. and Akstin, K.C. (1998) Determining rates of chemical weathering in soils-solute transport versus profile evolution. Journal. Hydrology 209, 331-345.

Street, J.H., Anderson, R.S. and Paytan, A. (2012) An organic geochemical record of Sierra Nevada climate since the LGM from Swamp Lake, Yosemite. Quaternary Science Reviews 40, 89-106.

Sweevers, H., Peeters, A. and Van Grieken, R. (1995) Weathering of the Leinster Granite under ambient atmospheric conditions. Science of the Total Environment 167, 73-85.

Taylor, A. and Blum, J.D. (1995) Relation between soil age and silicate weathering rates determined from the chemical evolution of a glacial chronosequence. Geology 23, 979982.

Taylor, A.S., Blum, J.D., Lasaga, A.C. and MacInnis, I.N. (2000) Kinetics of dissolution and Sr release during biotite and phologopite weathering. Geochimica Cosmochimica Acta 64, 1191-1208.

Thorn, C.E., Darmody, R. G.,Dixon. J. C., Schyter, P. (2002) Weathering rates of buried machine-polished rock disks, Karkevagge, Swedish Lapand. Earth Surface Processes and Landforms 27, 831-845.

Turner, B.F., Stallard, R.F. and Brantley, S.L. (2003) Investigation of in situ weathering of quartz diorite bedrock in the Rio Icacos basin, Luquillo Experimental Forest, Puerto Rico. Chemical Geology 202, 313-341.

van Grinsven, J.J.M. and Reimsdijk, W.H. (1992) Evaluation of batch and column techniques to measure weathering rates in soils. Geoderma 52, 41-57.

White, A.F. and Yee, A. (1985) Aqueous oxidation-reduction kinetics associated with coupled electron-cation transfer from iron containing silicates. Geochimica Cosmochimica Acta 49, 1263-1275.

White, A.F. and Brantley, S.L. (2003) The effect of time on the weathering of silicate minerals: Why do weathering rates differ in the laboratory and field? Chemical Geology 202, 479506.

White, A.F. and Buss, H.L. (2014) 7.4 - Natural Weathering Rates of Silicate Minerals, in: Drever, J.I. (Ed.), Treatise on Geochemistry (Second Edition). Elsevier, Oxford, pp. 115155.

White, A.F., Blum, A.E., Schulz, M.S., Bullen, T.D., Harden, J.W. and Peterson, M.L. (1996) Chemical weathering of a soil chronosequence on granitic alluvium 1. Reaction rates based on changes in soil mineralogy. Geochimica Cosmochimica Acta 60, 2533-2550

White, A.F., Blum, A.E., Schulz, M.S., Vivit, D.V., Larsen, M. and Murphy, S.F. (1998) Chemical weathering in a tropical watershed, Luquillo Mountains, Puerto Rico: I. Longterm versus short-term chemical fluxes. Geochimica Cosmochimica Acta 62, 209-226.

White, A.F., Bullen, T.D., Vivit, D.V. and Schulz, M.S. (1999a) The role of disseminated calcite in the chemical weathering of granitoid rocks. Geochimica Cosmochimica Acta 63, 19391953.

White, A.F., Blum, A.E., Bullen, T.D., Vivit, D.V., Schulz, M. and Fitzpatrick, J. (1999b) The effect of temperature on experimental and natural weathering rates of granitoid rocks. Geochimica Cosmochimica Acta 63, 3277-3291.

White, A.F., Blum, A.E., Stonestrom, D.A., Bullen, T.D., Schulz, M.S., Huntington, T.G. and Peters, N.E. (2001) Differential rates of feldspar weathering in granitic regoliths. Geochimica Cosmochimica Acta 65, 847-869. 37-59. 
White, A.F., Blum, A.E., Schulz, M.S., Huntington, T.G., Peters, N.E. and Stonestrom, D.A. (2002) Chemical weathering of the Panola Granite: Solute and regolith elemental fluxes and the dissolution rate of biotite, in: Hellmann, R., Wood, S.A. (Eds.), Water-rock Interaction, Ore Deposits, and Environmental Geochemistry: A tribute to David A. Crerar. The Geochemical Society, 7 pp. 37-59.

White, A.F., Schulz, M.S., Lowenstern, J.B., Vivit, D.V. and Bullen, T.D. (2005a) The ubiquitous nature of accessory calcite in granitoid rocks: Implications for weathering, solute evolution and petrogensis. Geochimica Cosmochimica Acta 69, 1455-1471.

White, A.F., Schulz, M.S., Vivit, D.V., Blum, A.E., Stonestrom, D.A. and Harden, J. (2005b) Chemical weathering of a soil chronosequence on granitic alluvuim: III Hydrochemical evolution and comtemporary solute fluxes and rates. Geochemica Cosmochimica Acta 69, 1975-2005.

White, A.F., Schulz, M.S., Vivit, D.V., Blum, A.E., Stonestrom, D.A. and Anderson, S.P. (2008) Chemical weathering of a marine terrace chronosequence, Santa Cruz, California I: Interpreting rates and controls based on soil concentration-depth profiles. Geochimica Cosmochimica Acta 72, 36-68.

Yokoyama, T. and Matsukura, Y. (2006) Field and laboratory experiments on weathering rates of granodiorite: Separation of chemical and physical processes. Geology 34, 809-812.

Figure Captions

Figure 1. Relationship between secondary Fe precipitation and BET surface areas. (a) Stereo microscope image of secondary Fe-hydroxides, likely from dissolution of pyrite cementing secondary silicates from the fresh Merced column. Aggregate is $\sim 2 \mathrm{~mm}$ in diameter. (b) Secondary Fe-hydroxides coating feldspar grain in the reacted fresh Merced column $5 \mathrm{~cm}$ from inlet of the column. (c) BET surface areas of reacted fresh granitoids measured along column length (labeled as Depth) after reaction for 13.8 years. (d) Surface areas of reacted samples after Fe extraction by DCB. Also included are bulk surface areas of unreacted starting material.

Figure 2. Column pore water flow characteristics. (a) Fresh and weathered Merced granitoid flow rates based on effluent volumes collected over approximately one week intervals. Averages are indicated by horizontal lines (b) Cumulative volumes collected over the course of the fresh granitoid experiments. (c) Example of measured and fitted breakthrough curves with $\mathrm{MgCl}_{2}$ solution displacing water in fresh Merced granitoid. $\mathrm{K}_{\mathrm{sat}}$ (red line) is the saturated hydraulic conductivity during the displacement and $\mathrm{C}$ and $\mathrm{C}_{\mathrm{in}}$ are the effluent and influent concentrations, respectively. 
Figure 3. Effluent concentrations as functions of time for fresh (solid red circles) and weathered (open black circles) Merced granitoids. Outer plots contain complete data sets. Large solute variability's measured between 1.7 and 2.5 years reflect experimentally imposed temperature variations of between 5 and $34^{\circ} \mathrm{C}$ (White et al., 1999b). Inserts show concentrations measured between 5 and 13.8 years of reaction time (data in Table 5; supplemental tables). Trends are linear regressions to data.

Figure 4. (a) Column pore-water $\mathrm{pH}$ measured by rapid step-wise pore water displacement at the conclusion of the fresh (F) and weathered (W) granitoid experiments. Also shown are $\mathrm{pHs}$ of input solutions (5\% $\mathrm{CO}_{2}$ in DI water) and average $\mathrm{pHs}$ measured in collection bottles. (b-e) Relative proportions of major $\mathrm{NH}_{4}$-acetate exchangeable cations measured at the conclusion of the fresh granitoid experiments.

Figure 5. Extent of effluent thermodynamic saturation with respect to (a-c) secondary and (d-f) primary minerals using the PHREEQC speciation code based on effluent compositions. Solid horizontal lines denote fully saturated conditions.

Figure 6. Relationship between flow rate and effluent Na concentrations for fresh granitoids. Predicted trends assuming transport-limited reactions (horizontal lines) and kineticallylimited reactions (convex lines). The lines intercept at average flow and concentration for times greater than four years. While not shown, a similar relationship exists for the Rio Icacos data.

Figure 7. Predicted mineral contributions (mmoles) to column effluents over time. Positive values indicate additions from dissolution and negative values subtractions resulting from precipitation. Inserts are expanded scales for times ranging from 2 to 13 years. Elemental constrains are described in text. Mineral compositions are from White et al. (1999a).

Figure 8. Ca/Sr and ${ }^{87} \mathrm{Sr} /{ }^{86} \mathrm{Sr}$ ratios of effluents produced from fresh (a-c) and weathered (d-e) granitoids compared with corresponding calcite, plagioclase, and biotite ratios. Circles correspond to solute samples (labels are reaction times in years). Dashed lines are solute 
mixing lines based on plagioclase and calcite inputs. Calcite contents (ppm) are also indicated. Arrows indicate ${ }^{87} \mathrm{Sr} /{ }^{86} \mathrm{Sr}$ value of biotite (off scale). Sr was not measureable (below detection) in biotites so the position of the biotite arrows on the $\mathrm{Ca} / \mathrm{Sr}$ axes are arbitrary. Effluents from the Tertiary Rio Icacos quartz diorite produced very small variations in $\mathrm{Sr}$ isotopic ratios and are not shown. Mineral data are from Bullen et al., (1999) and White et al. (2005a). Estimates for average watershed ratios are included on the weathered granitoid plots. Data from Blum et al. 1994; Bullen et al 1996; Bullen et al., 1999; Clow et al. 1997; and Pett-Ridge et al. 2009.

Figure 9. Plagioclase dissolution rates calculated over time for fresh and weathered granitoids (this study) compared to experimental and natural rates reported in the literature (data summarized from (White and Brantley, 2003; Bandstra et al., 2008 and White and Buss, 2014). Significant excursions at times between 1.2 and 1.5 yrs correspond to induced temperature changes (White et al., 1999b). Rectangular boxes enclose longer term data (4.0 to 13.8 yrs; Table 5 and Fig. 10). Dashed line corresponds to linear fits to all literature data as described in White and Brantley (2003). Starred data are literature rates reported for fiel-sites associated granitoids used in the present study.

Figure 10 Cumulative solute $\mathrm{Na}$ outputs from fresh granitoids calculated from effluent $\mathrm{Na}$ concentration and column discharge volume. Solid lines correspond to linear regression fits to data between 4 and 13.8 years with residuals shown in the lower right inserts. The horizontal zero line corresponds to a perfect fit to the linear regression.

Figure 11. CrunchFlow simulations showing (a) increasing plagioclase thermodynamic saturation and (b) decreasing reaction rates with declining flow rates. Data derived using both transition state theory (TST) and parallel rate law (PRL) subroutines as applied to example computational nodes at the inlet and outlet of the column $(0.05$ and $0.95 \mathrm{~m})$. (c) comparison of measured fractional plagioclase losses (fraction of residual plagioclase remaining relative to initial concentrations) with depth over Merced Riverbank soil (data points) with simulations using baseline (thin blue line) and best-fit assumptions (thick black line) employing the parameters listed in Table 6. 
Table 1. Summary of experimental granite weathering studies.

\begin{tabular}{|c|c|c|c|c|c|}
\hline Material & Experiment type & Duration & $\mathrm{pH}$ & Primary measurements & Reference \\
\hline Old Rag granite, VA, USA & Columns, flow 3-12 ml/hr & 365 days & $2-5$ & Major solutes/clay formation & Afifa et al., 1985 \\
\hline Biotite granite, Chile & Flow-thru reaction cells & $4200 \mathrm{hrs}$ & 1 & $\mathrm{U}$ isotopes & Andersen et al., 2009 \\
\hline Elat granite, Israel & Batch hand-shaken bottles & $168 \mathrm{hrs}$ & $0.3-2$ & Fe isotopes & Chapman et al., 2009 \\
\hline El-Capitan granite, CA, USA & Disks in soils, Sweden & $5-10 \mathrm{yrs}$ & $2-8$ & Bulk weight loss & Dixon et al., 2001; Thorn et al., 2002 \\
\hline Abukuma granodioirite, Japan & Flow-thru reaction cells & $4200 \mathrm{hrs}$ & 1 & $\mathrm{~Pb} / \mathrm{Sr}$ isotopes & Erel et al. 2004 \\
\hline Granite, GA, USA & Flow-thru reaction cells & $4200 \mathrm{hrs}$ & 1 & Solutes, surface coating and saturation & Ganor et al., 2005 \\
\hline Elat granite, Israel & Batch hand-shaken bottles & $2600 \mathrm{hrs}$ & 1 & $\mathrm{REE}, \mathrm{Pb}$ isotopes & Harlavan et al., 2002 \\
\hline Toulomne granite,CA USA & Columns, flow $1.7-2.6 \mathrm{ml} / \mathrm{hr}$ & 45 weeks & 6 & Major solutes, REE, role of citrate & Hausrath et al., 2009 \\
\hline Toulomne granite,CA USA & Lab, mechanical shaking & 4 weeks & 6 & Solutes, effects of organics & Neaman et al., 2006 \\
\hline Boulder Ck. granodioirite CO, USA & Rectangular blocks & 26 days & nd & Effects of salt solutions & Rivas et al., 2003 \\
\hline Elat granite, Israel & Column, flow $3.1 \mathrm{ml} / \mathrm{hr}$ & $5794 \mathrm{hrs}$ & 1 & Major solutes, $\mathrm{Ca}$ and $\mathrm{Mg}$ isotopes & Ryu et al., 2011 \\
\hline Granitoids & Slabs & $2 \mathrm{yrs}$ & 3.7 & Rain on solutes, effects on mass losess & Sweevers et al., 1995 \\
\hline Granitoids, global distribution & Batch, hand shaken bottles & 75 days & $6.5-8.5$ & Major solutes, effects of trace calcite & White et al., 2005a \\
\hline Granitoids (this study) & Columns, flow $6-10 \mathrm{ml} / \mathrm{hr}$ & $14000 \mathrm{hrs}$ & $5-6$ & Major solutes, effects of trace calcite & White et al., 1999a \\
\hline Granitoids (this study) & Columns, flow $6-10 \mathrm{ml} / \mathrm{hr}$ & $20000 \mathrm{hrs}$ & $5-6$ & Major solutes, effects of temperature & White et al., 1999b \\
\hline Leinster granite, Ireland & Sawed tablets, field and lab & $1-10 \mathrm{yrs}$ & $6-7$ & Bulk weight loss & Yokoyama \& Matsukura, 2006 \\
\hline
\end{tabular}


Table 2. Description of granitoid rocks used in experimental study.

\begin{tabular}{|c|c|c|c|c|c|}
\hline Location & Rock & Dominant Mineralogy & Age & Source & Reference \\
\hline $\begin{array}{l}\text { Upper Merced River, } \\
\text { Yosemite, National Park, } \\
\text { CA, USA }\end{array}$ & $\begin{array}{l}\text { Granodiorite of } \\
\text { Arch Rock }\end{array}$ & $\begin{array}{l}\text { Quartz, olgioclase, } \\
\text { microcline, biotite, } \\
\text { hornblende }\end{array}$ & Cretaceous & $\begin{array}{l}\text { Road cut and } \\
\text { weathered exfoliated } \\
\text { surface }\end{array}$ & $\begin{array}{l}\text { Calkins et al., } \\
1985\end{array}$ \\
\hline $\begin{array}{l}\text { Loch Valle, Rocky Mtn. } \\
\text { National Park, CO, USA }\end{array}$ & $\begin{array}{l}\text { Silver Plume } \\
\text { granite }\end{array}$ & $\begin{array}{l}\text { Quartz, olgioclase, } \\
\text { microcline, biotite, }\end{array}$ & Precambrian & $\begin{array}{l}\text { Fresh and weathered } \\
\text { surface exposures }\end{array}$ & Cole, 1977 \\
\hline $\begin{array}{l}\text { Panola Mtn. Research } \\
\text { Watershed, GA, USA }\end{array}$ & $\begin{array}{l}\text { Panola granite } \\
\text { (granodiorite) }\end{array}$ & $\begin{array}{l}\text { Quartz, oligoclase, } \\
\text { microcline, biotite } \\
\text { muscovite }\end{array}$ & $\begin{array}{l}\text { Mississippian- } \\
\text { Pennslyanian }\end{array}$ & $\begin{array}{l}\text { Drill core, fresh and } \\
\text { weathered fractures }\end{array}$ & $\begin{array}{l}\text { Higgins et } \\
\text { al., } 1988\end{array}$ \\
\hline $\begin{array}{l}\text { Rio Icacos watershed, } \\
\text { Luquillo Mtns., PR }\end{array}$ & $\begin{array}{l}\text { Rio Blanco quartz } \\
\text { diorite }\end{array}$ & $\begin{array}{l}\text { Quartz, andesine, } \\
\text { biotite, hornblende, } \\
\text { microcline }\end{array}$ & Tertiary & $\begin{array}{l}\text { Road cut and } \\
\text { weathered core stone }\end{array}$ & Seiders, 1971 \\
\hline
\end{tabular}


Table 3. Comparsion of major physical properties, hydrology and compositions of the fresh Merced granitoid column experiment and the $250 \mathrm{ka}$ Riverbank soil at a depth of 5.5 m. Soil data from Harden (1987), White et al. (1996, 2002), and Stonestrom et al., 1998).

\begin{tabular}{lcc}
\hline Parameter & Column & Soil \\
\hline Total weathering depth $(\mathrm{m})$ & 0.90 & 5.5 \\
Soil state weathering duration (yrs) & 13.8 & $2.5 \times 10^{4}$ \\
Porosity (\%) & 40 & 38 \\
Rate of fluid input $\left(\mathrm{m} \mathrm{yr}^{-1}\right)$ & 160 & 0.060 \\
Average pore water residence time (yrs) & 0.056 & 20.0 \\
Clay (wt \%) & 0 & 12.3 \\
Plagiolcase (wt\%) & 36 & 33 \\
Plagioclase surface area $\left(\mathrm{m}^{2} \mathrm{~g}^{-1}\right)$ & 0.18 & 0.31 \\
Fluid saturation $(\%)$ & 100 & $40-80$ \\
Saturated hydraulic conductivity $\left(\mathrm{m} \mathrm{s}^{-1}\right)$ & $3.7 \times 10^{-6}$ & $3.5 \times 10^{-6}$ \\
Unsaturated hydraulic conductivity & na & $9.4 \times 10^{-8}-8.9 \times 10^{-10}$ \\
Solute Na at maximum depth $(\mu \mathrm{molar})$ & 1.6 & 100 \\
\hline
\end{tabular}

${ }^{a}$ not applicable 
Table 4 BET-measured surface areas $\left(\mathrm{S}_{\mathrm{BET}} ; \mathrm{m}^{2} \mathrm{~g}^{-1}\right)$ of bulk granitoid samples at the start $(5 / 14 / 96)$, intermediate and end times of experiments. Data in parenthesis are surface areas after DCB extraction for Fe. $S_{\mathrm{BET}}$ data are plotted in Fig. 1c and d.

\begin{tabular}{lccccc}
\hline & $\begin{array}{c}\text { Starting material } \\
1 / 28 / 1998\end{array}$ & $\begin{array}{c}\text { Inlet } \\
1.6 \mathrm{yrs}\end{array}$ & $\begin{array}{c}\text { Inlet } \\
6.2 \mathrm{yrs}\end{array}$ & $\begin{array}{c}\text { Inlet } \\
13.8 \mathrm{yrs}\end{array}$ & $\begin{array}{c}\text { Outlet } \\
13.8 \mathrm{yrs}\end{array}$ \\
\hline Merced (F) & $0.077(0.119)$ & 0.181 & nd $^{\mathrm{a}}$ & $5.39(0.704)$ & $0.313(0.174)$ \\
Rio Icacos (F) & $0.103(0.228)$ & 0.242 & nd & $6.74(1.26)$ & $0.614(0.463)$ \\
Loch Vale (F) & $0.084(0.105)$ & 0.155 & nd & $0.442(0.290)$ & $0.506(0.213)$ \\
Panola (F) & $0.088(0.104)$ & 0.244 & 0.298 & $1.15(0.316)$ & $0.619(0.280)$ \\
& & & & & \\
Merced (W) & 0.79 & 0.34 & nd & 1.97 & 1.71 \\
Rio Icacos (W) & 2.91 & 2.37 & nd & 6.63 & 4.09 \\
Loch Vale (W) & 0.15 & 0.21 & nd & 0.63 & 0.68 \\
Panola (W) & 4.12 & 2.35 & 5.33 & 5.62 & 5.88 \\
\hline
\end{tabular}

${ }^{a}$ not determined 
Table 5. Effluent parameters and compositions of selective effluent samples collected during the last four years of granitoid reaction (shorter term data previously reported in White et al., 1999a and 1999b).

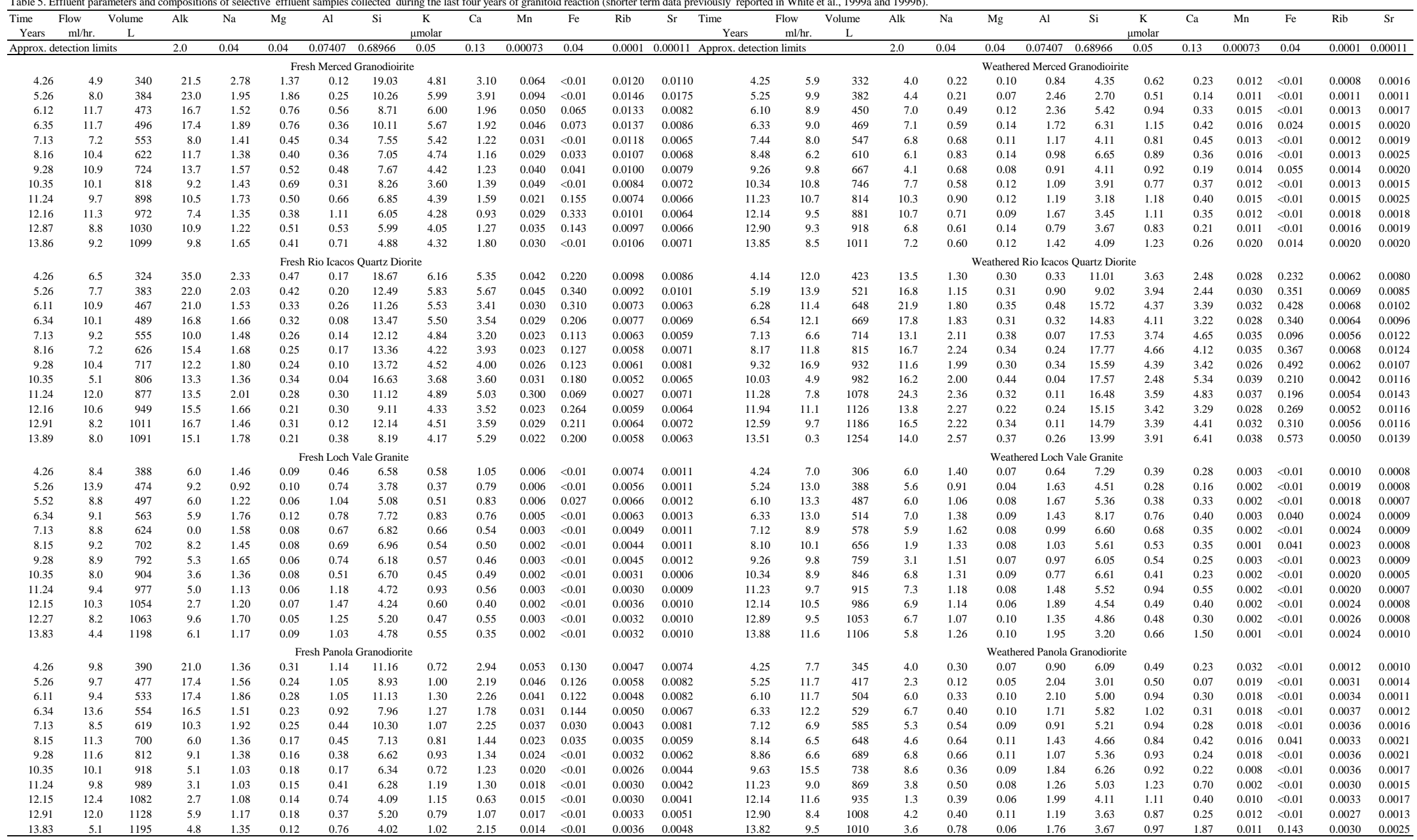


Table 6. Selective parameters used in CrunchFlow simulations of short- and long- term plagioclase weathering of the Merced granitoid and Merced Riverbank soil, respectively. Model parameters for the long-term simulations are taken from Moore et al., 2012, whereas parameters for short-term simulations are from laboratory measurements reported in the present study.

\begin{tabular}{|c|c|c|c|}
\hline CrunchFlow parameters & Long-term & Short-term & Secondary species \\
\hline \multicolumn{3}{|c|}{ Boundary/initital conditions } & $\mathrm{Al}(\mathrm{OH})^{2+}$ \\
\hline Temp ${ }^{\circ} \mathrm{C}$ & 22 & 22 & $\mathrm{AlO}_{2}^{-}$ \\
\hline $\mathrm{CO}_{2}(\mathrm{~g})$ bars & 0.05 & 0.05 & $\mathrm{AlOH}^{2+}$ \\
\hline $\mathrm{pH}$ & 5.79 & 4.67 & $\mathrm{CaCl}^{+}$ \\
\hline Solid Density $\left(\mathrm{g} \mathrm{m}^{-3}\right)$ & 2.6 & 2.6 & $\mathrm{CaCl}_{2}(\mathrm{aq})$ \\
\hline \multirow[t]{2}{*}{ Porosity $\left(\mathrm{m}^{3} \mathrm{~m}^{-3}\right)$} & 0.34 & 0.42 & $\mathrm{CaCO}_{3}(\mathrm{aq})$ \\
\hline & & & $\mathrm{CaHCO}^{3+}$ \\
\hline \multicolumn{3}{|c|}{ Primary species concentration ( $m o l \mathrm{~kg}^{-1}$ ) } & $\mathrm{CaOH}^{+}$ \\
\hline $\mathrm{Na}^{+}$ & $1.98 \mathrm{E}-04$ & $1.00 \mathrm{E}-09$ & $\mathrm{CO}_{3}{ }^{2-}$ \\
\hline $\mathrm{Al}^{3+}$ & $2.08 \mathrm{E}-07$ & $1.00 \mathrm{E}-09$ & $\mathrm{H}_{2} \mathrm{SiO}_{4}{ }^{2-}$ \\
\hline $\mathrm{Mg}^{2+}$ & 7.64E-05 & 1.00E-09 & $\mathrm{HAlO}_{2}(\mathrm{aq})$ \\
\hline $\mathrm{Ca}^{2+}$ & $1.06 \mathrm{E}-04$ & $1.00 \mathrm{E}-09$ & $\mathrm{HCl}(\mathrm{aq})$ \\
\hline $\mathrm{K}^{+}$ & 7.03E-05 & $1.00 \mathrm{E}-09$ & $\mathrm{HCO}_{3}^{-}$ \\
\hline $\mathrm{Sr}^{2+}$ & 1.00E-09 & 1.00E-09 & $\mathrm{HSiO}_{3}^{-}$ \\
\hline $\mathrm{Fe}^{2+}$ & $1.00 \mathrm{E}-09$ & $1.00 \mathrm{E}-09$ & $\mathrm{KCl}(\mathrm{aq})$ \\
\hline $\mathrm{Fe}^{3+}$ & $1.00 \mathrm{E}-09$ & $1.00 \mathrm{E}-09$ & $\mathrm{MgCl}^{+}$ \\
\hline $\mathrm{SiO}_{2}(\mathrm{aq})$ & $1.12 \mathrm{E}-06$ & $1.00 \mathrm{E}-09$ & $\mathrm{MgCO}_{3}(\mathrm{aq})$ \\
\hline $\mathrm{O}_{2}(\mathrm{aq})$ & $1.00 \mathrm{E}-02$ & $1.00 \mathrm{E}-02$ & $\mathrm{MgHCO}_{3}^{+}$ \\
\hline $\mathrm{Cl}^{-}$ & 2.72E-04 & 1.00E-09 & $\mathrm{NaAlO}_{2}(\mathrm{aq})$ \\
\hline \multirow[t]{2}{*}{$\mathrm{SO}_{4}{ }^{2-}$} & $9.88 \mathrm{E}-05$ & $1.00 \mathrm{E}-09$ & $\mathrm{NaCl}(\mathrm{aq})$ \\
\hline & & & $\mathrm{NaCO}_{3}^{-}$ \\
\hline \multicolumn{3}{|c|}{ Initial mineral abundance $\left(\mathrm{m}^{3} \mathrm{~m}^{-3}\right)$ and surface area $\left(\mathrm{m}^{2} \mathrm{~g}^{-1}\right)$} & $\mathrm{NaHCO}_{3}(\mathrm{aq})$ \\
\hline Plagioclase & $0.250(0.18)$ & $0.21(0.18)$ & $\mathrm{NaHSiO}_{3}(\mathrm{aq})$ \\
\hline K-Feldspar & $0.087(0.18)$ & $0.09(0.18)$ & $\mathrm{NaOH}(\mathrm{aq})$ \\
\hline Kaolinite & $0.035(12.0)$ & Trace (12.0) & $\mathrm{OH}^{-}$ \\
\hline Quartz & $0.243(0.18)$ & $0.21(0.18)$ & $\mathrm{SrCO}_{3}(\mathrm{aq})$ \\
\hline
\end{tabular}


Table 7. Baseline from experimental results are compared with best fit parameter values need to produce a closer model fit to longterm development of the Merced Riverbank soil plagioclase profile.

\begin{tabular}{|c|c|c|c|}
\hline Variable parameters & Units & Baseline & Best fit \\
\hline Plagioclase log k (FFE) & moles $\mathrm{m}^{2} \mathrm{~s}^{-1}$ & -13.1 & -14.1 \\
\hline Plagioclase $\log \mathrm{k}$ (CTE) & moles $\mathrm{m}^{2} \mathrm{~s}^{-1}$ & -14.9 & -15.1 \\
\hline Kaolinite $\log \mathrm{k}$ & moles $\mathrm{m}^{2} \mathrm{~s}^{-1}$ & -19.9 & -20.6 \\
\hline Flow rate & $\mathrm{m} \mathrm{yr}^{-1}$ & 0.06 & 0.0054 \\
\hline
\end{tabular}



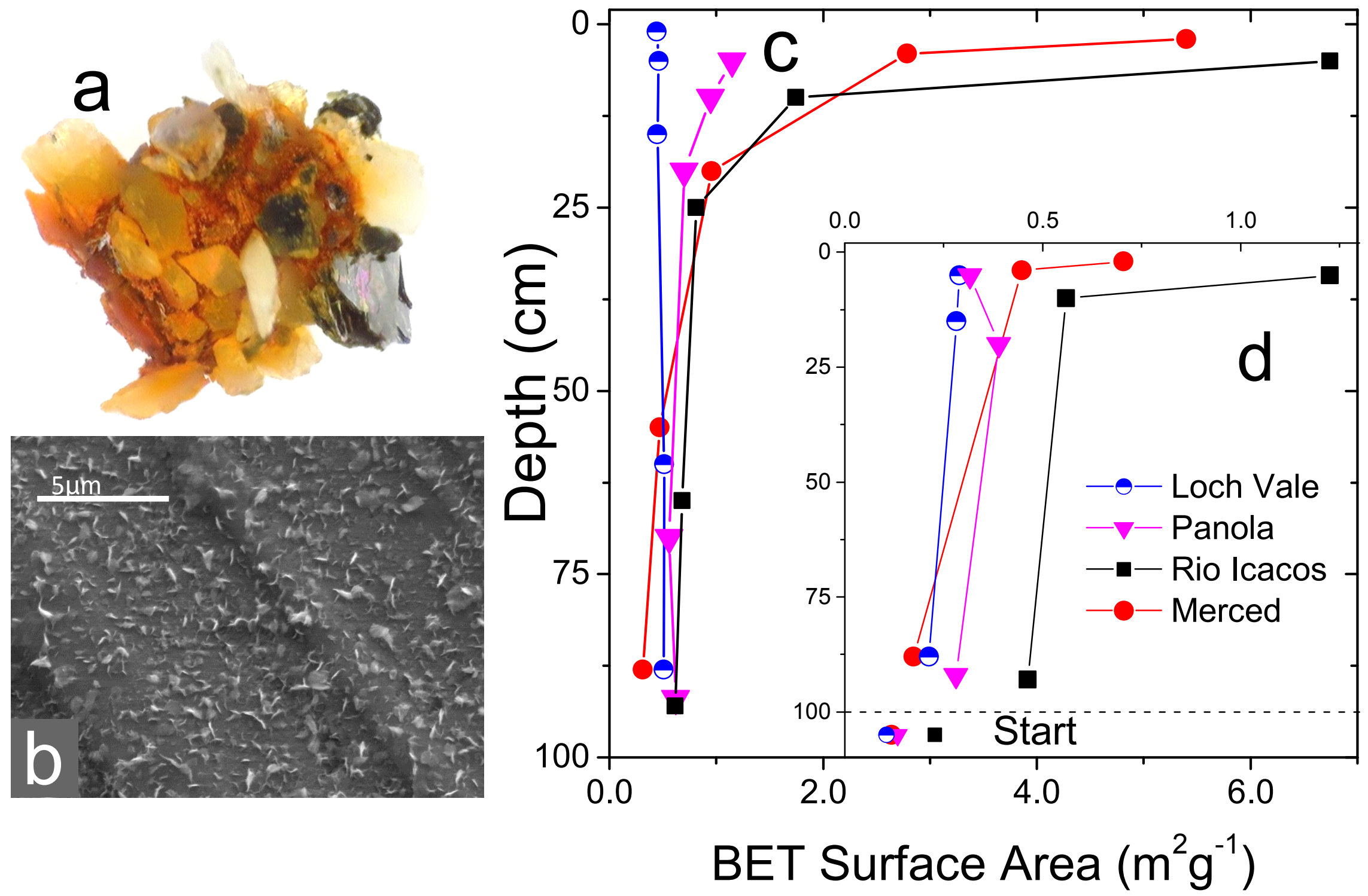

Figure 1 White et al. 

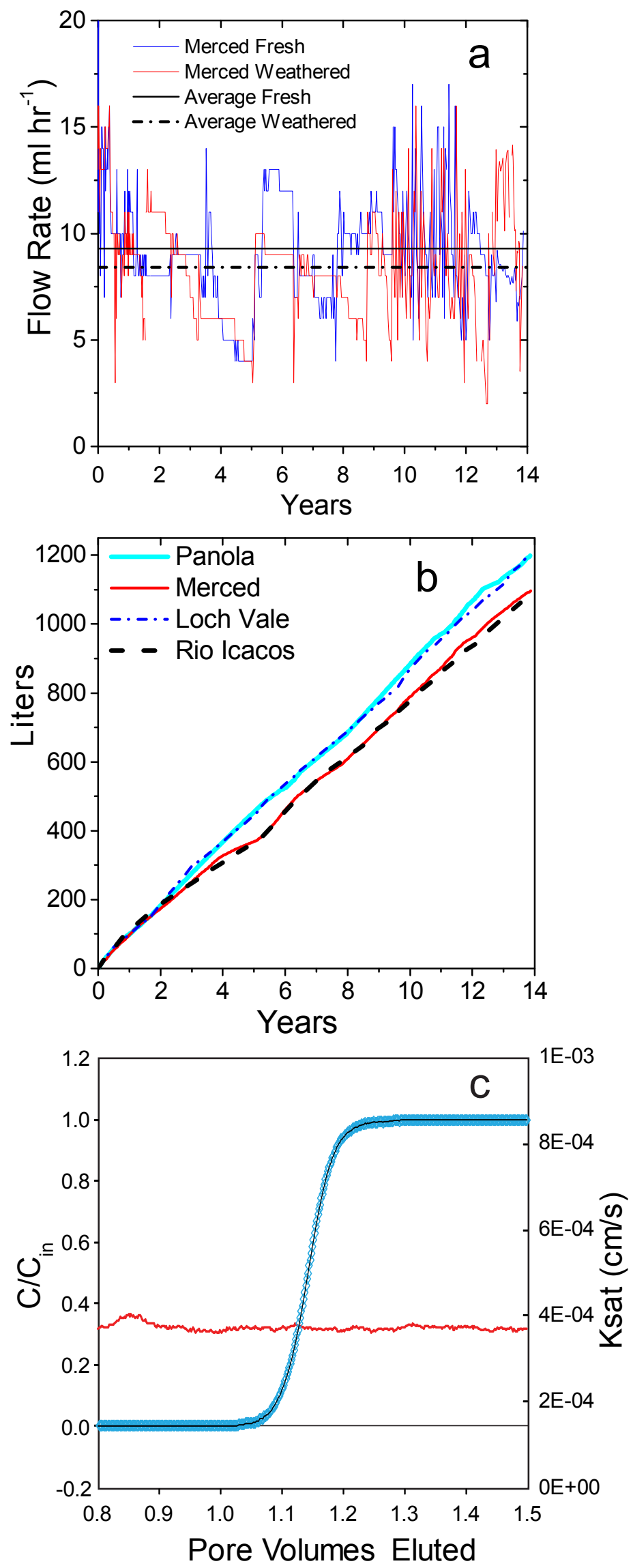

Figure 2 

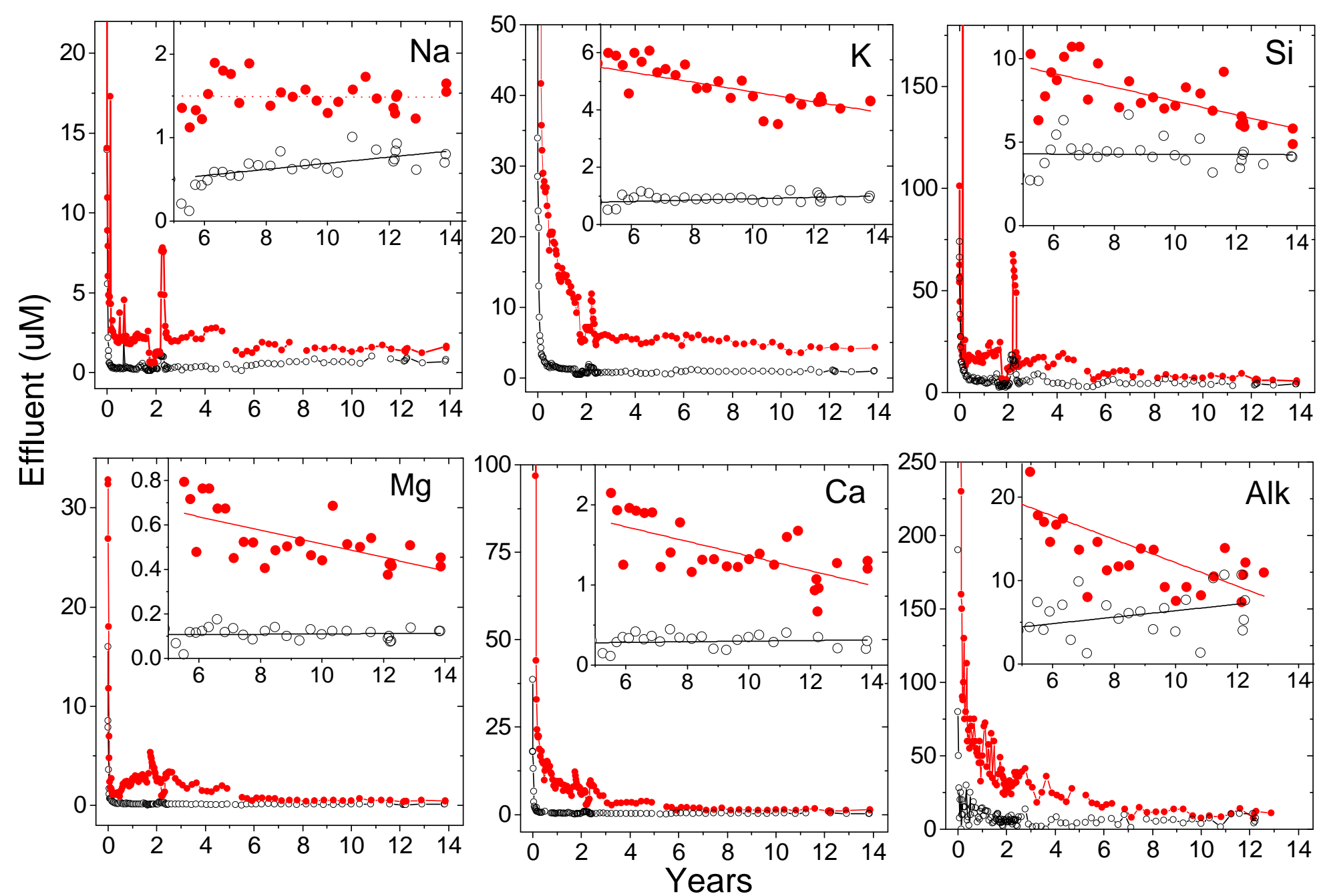


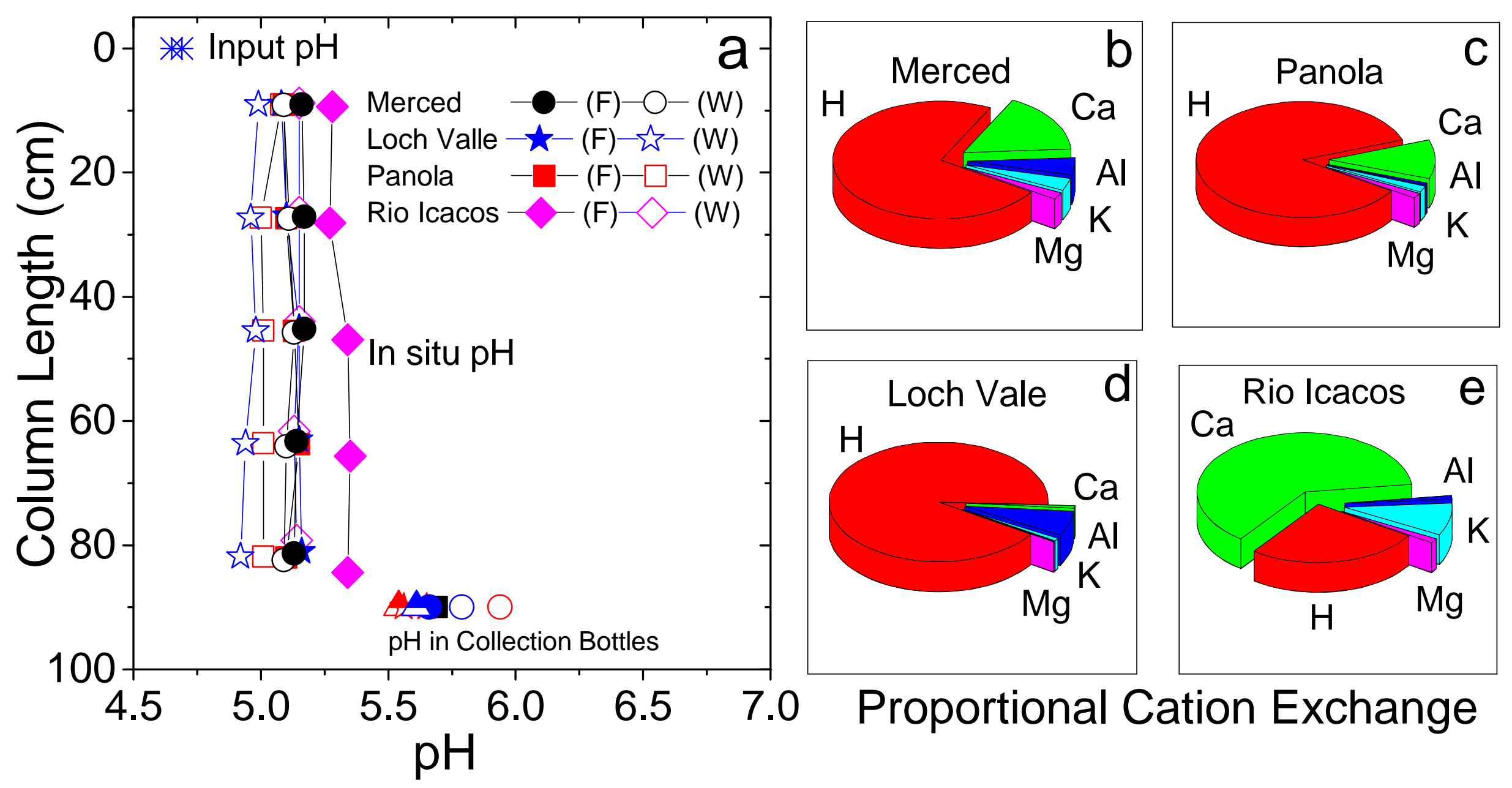




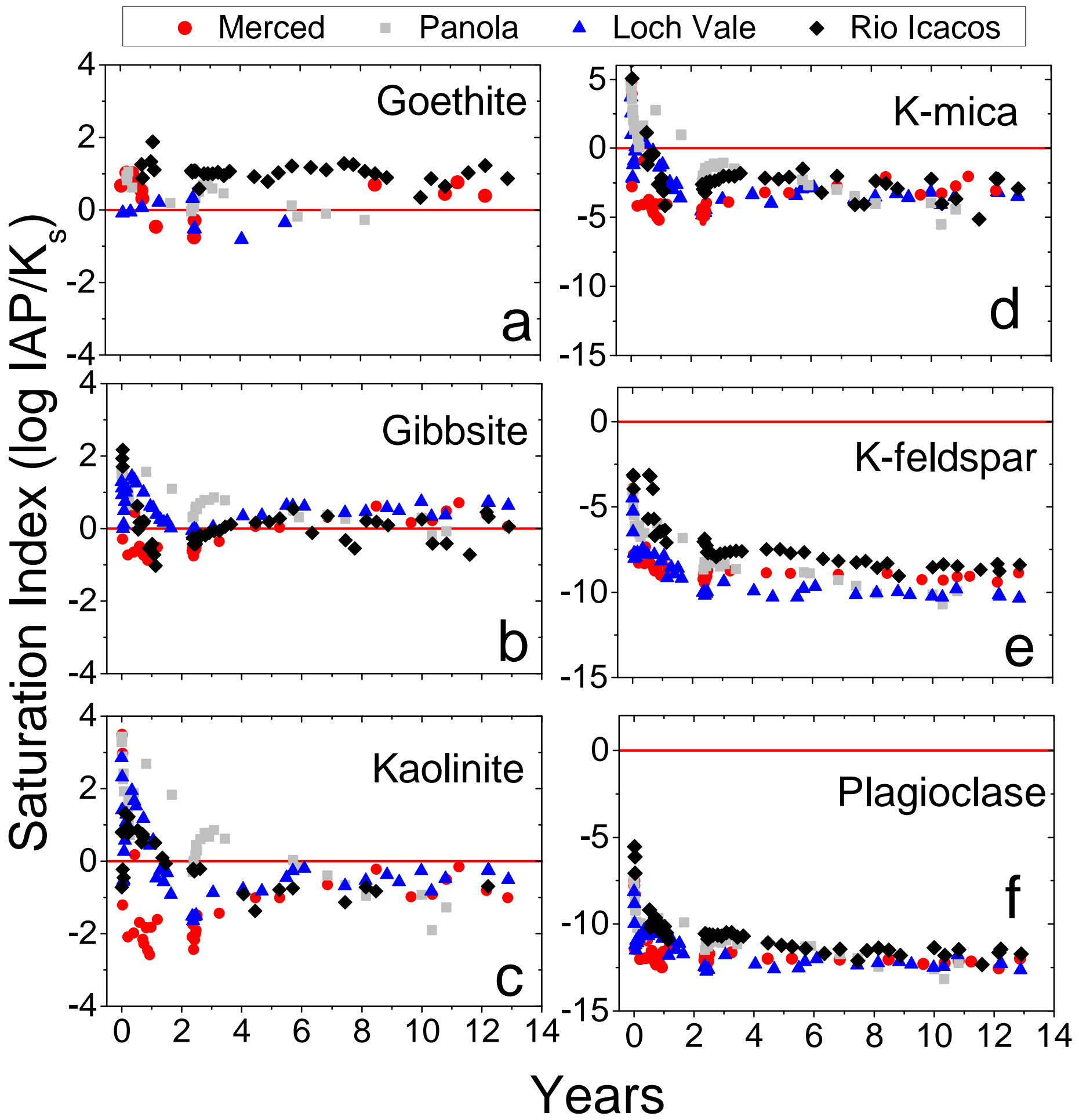



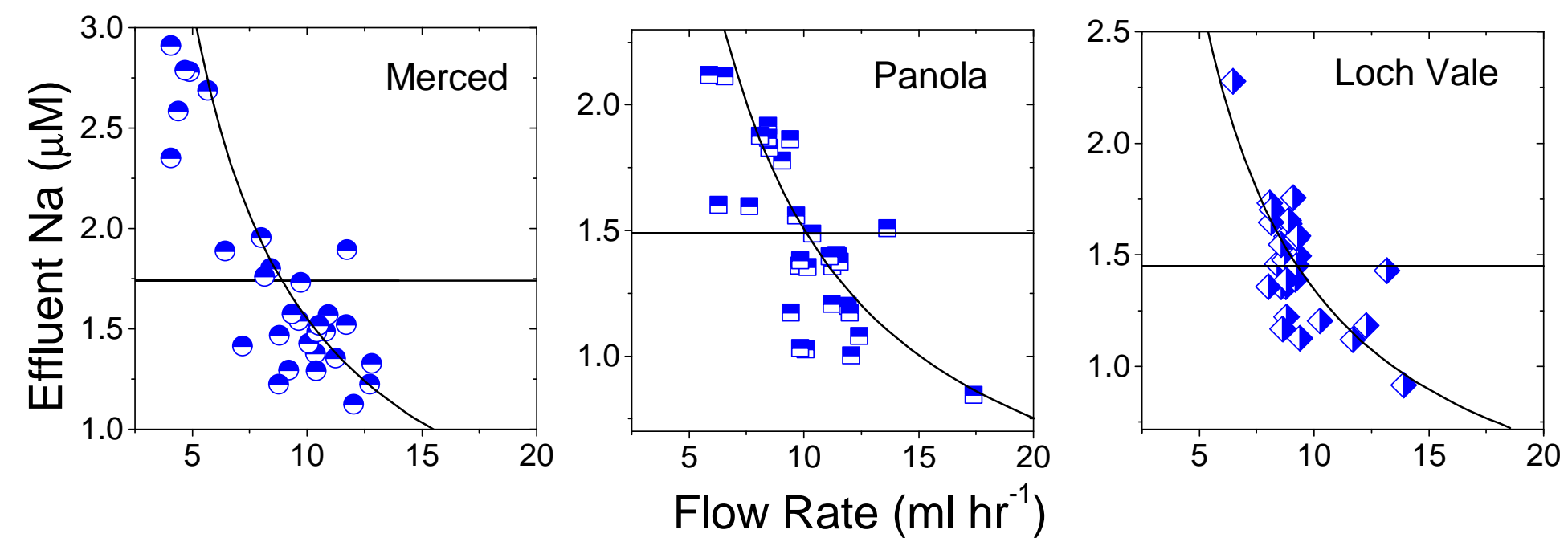

Flow Rate (ml hr ${ }^{-1}$ ) 
$\triangleleft$ Plag $\diamond$ Kspar $\because-$ Hornblende $>$ Biotite

* Kexchange - Calcite - Goethite $\checkmark$ Kaolinite

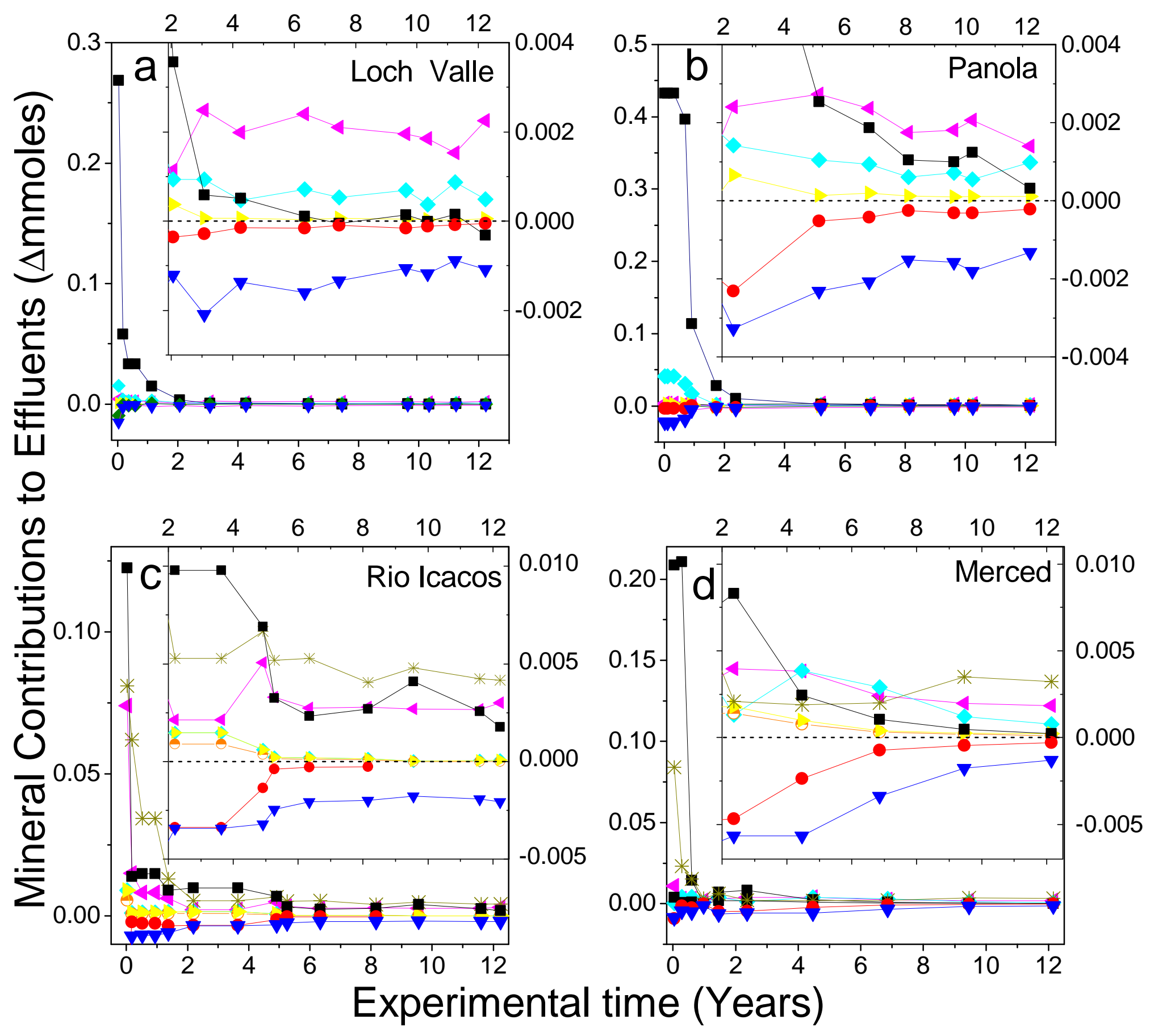




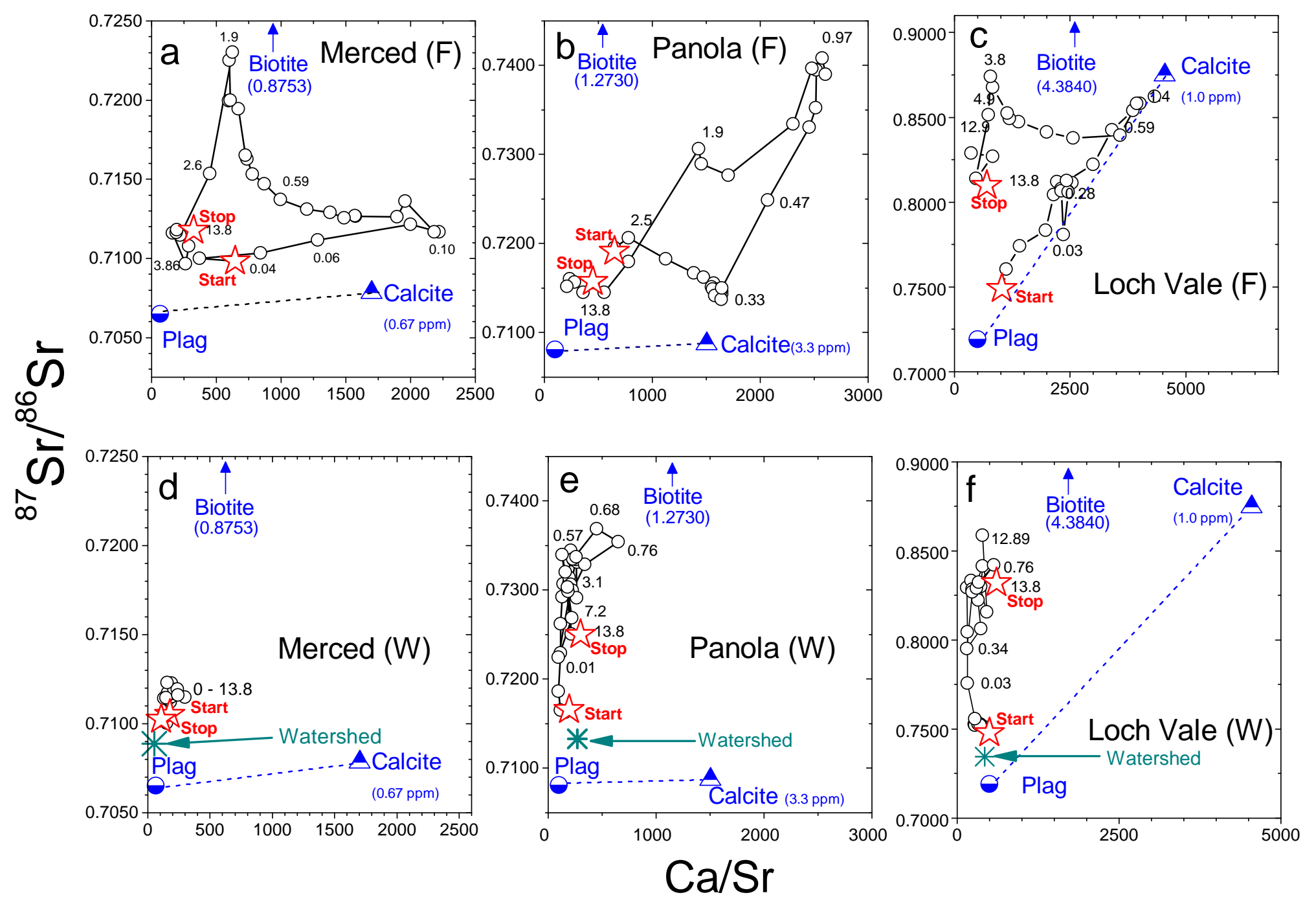


- Fresh granitoid plag. (this study) —W Weathered granitoid plag. (this study)

$\ominus$ Exper. plag (literature). $\ominus$ Natural plag (literature). - - - Regression fit

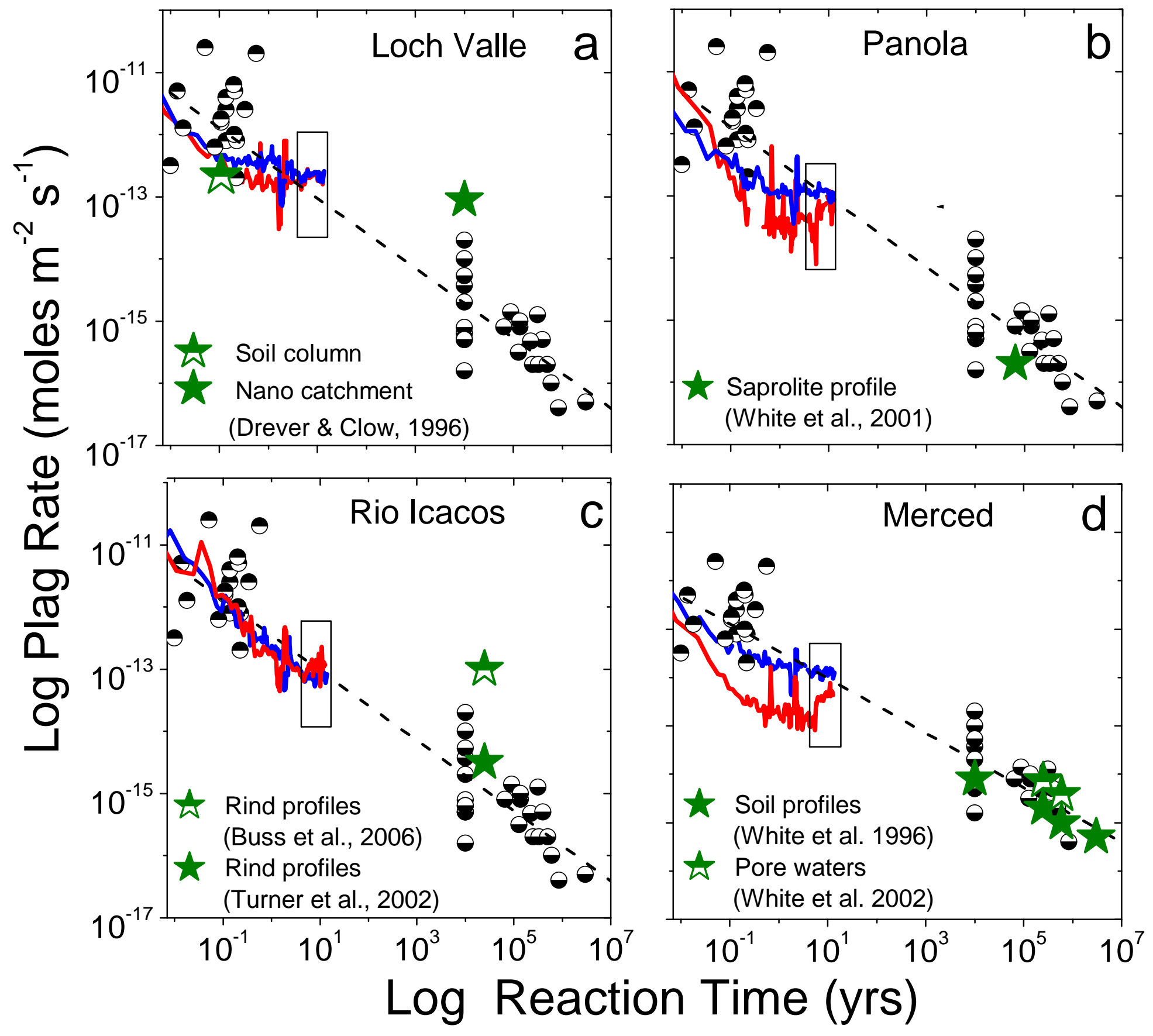


Time (years)
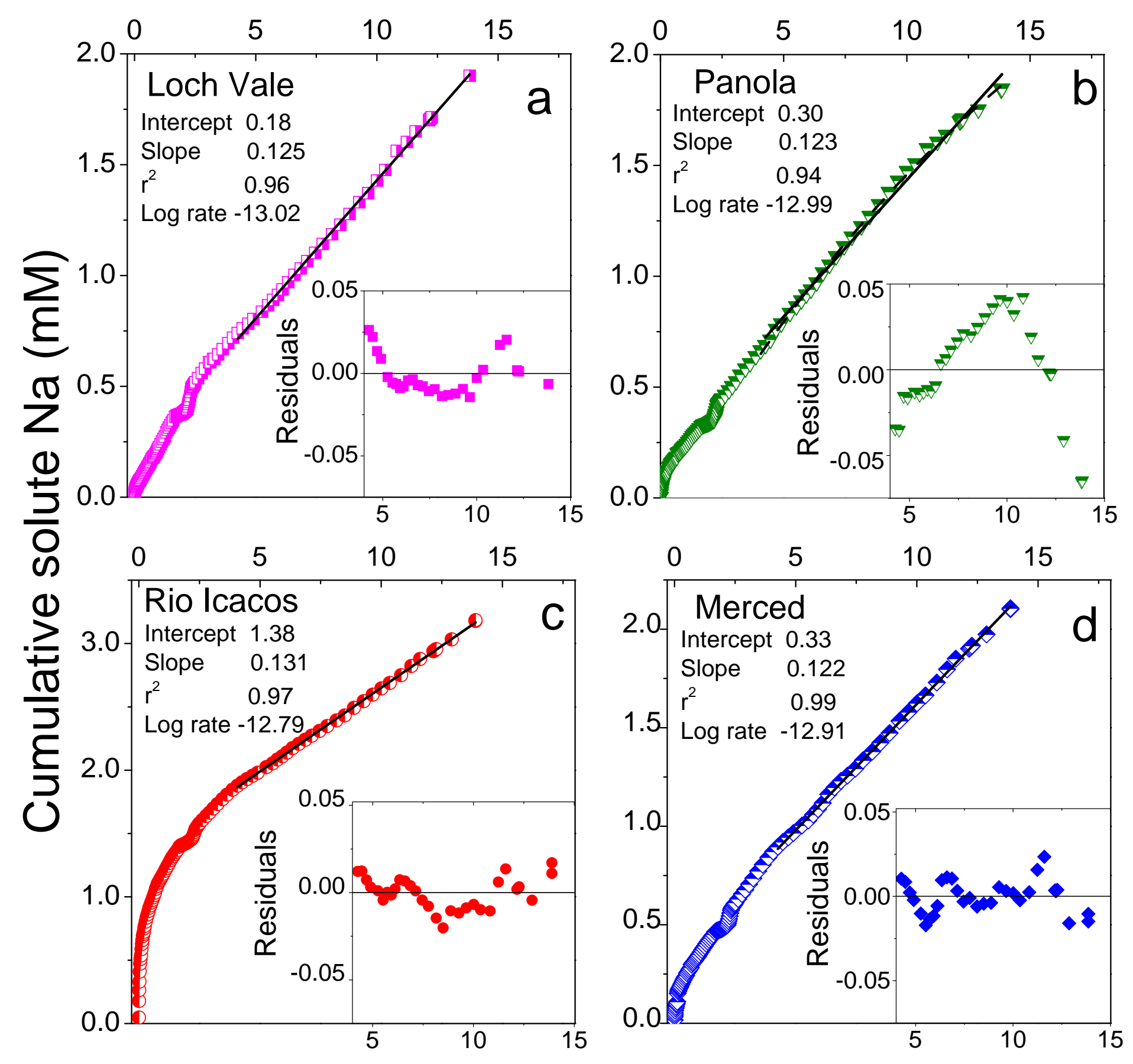

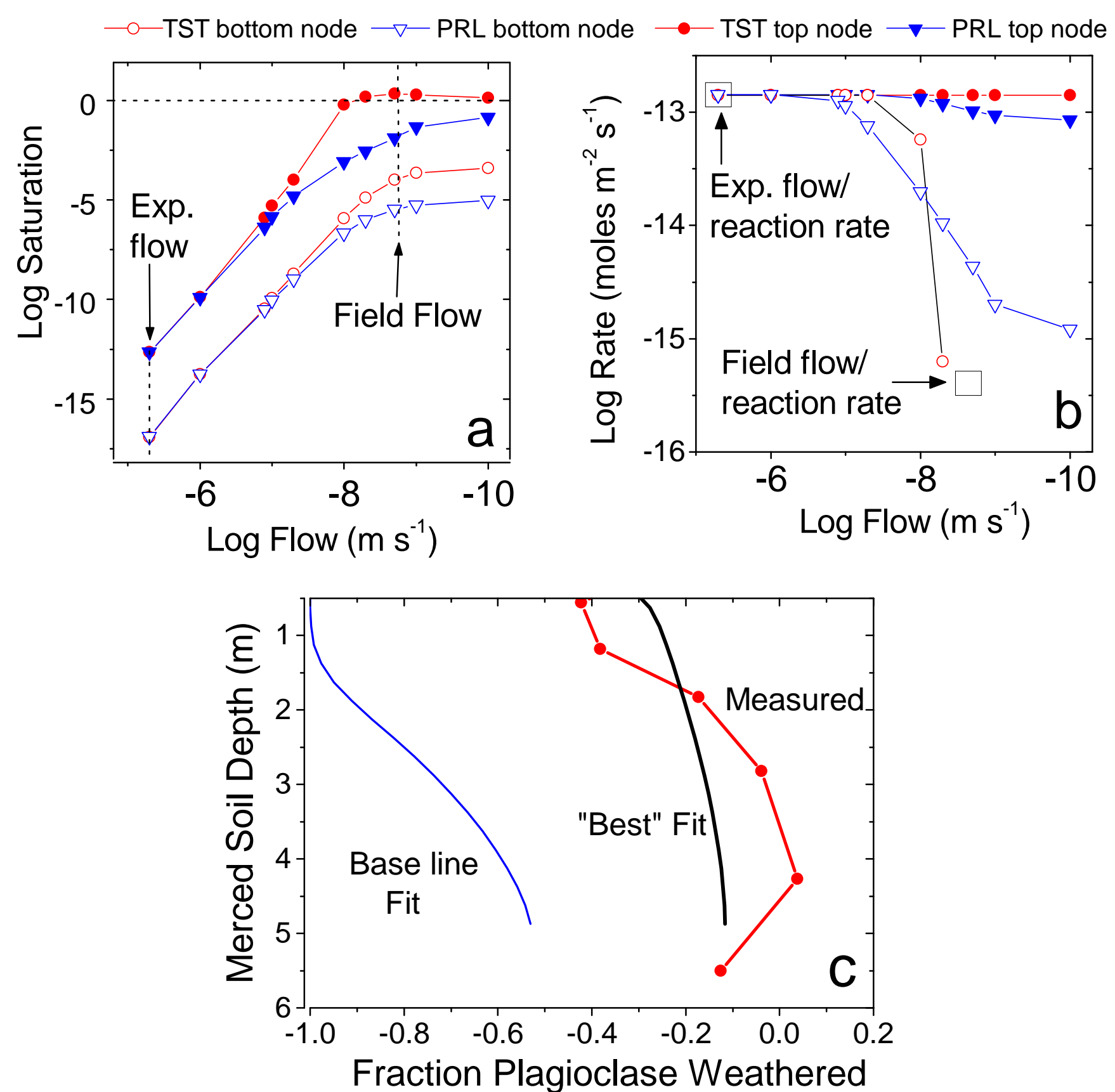

Fig 11. White et al. 